\title{
REGÍMENES NATURAL Y ARTIFICIAL DEL RÍO JÚCAR
}

\author{
Antonio Gil Olcina \\ Instituto Universitario de Geografía \\ Universidad de Alicante
}

\section{RESUMEN}

El ritmo natural del Júcar, que, a pesar de las copiosas sangrías de la Acequia Real y otras derivaciones, perduró hasta 1957, ha sido intensamente mediatizado y alterado por los hiperembalses para la regulación de las aguas de cabecera (Alarcón y, en el Cabriel, Contreras) y la segunda presa de Tous, cuya finalidad esencial es la laminación de avenidas.

Gran trascendencia revisten asimismo los bombeos masivos en el acuífero de la Mancha Oriental a partir de 1989, con incidencia muy negativa en la regularidad natural del Júcar, su caudal de base y memoria hiperanual.

Palabras clave: Régimen natural, alteración, hiperembalses, bombeos.

\section{RÉSUMÉ}

Le rythme naturel du Júcar qui continua jusqu'en 1957, malgré les copieuses saignées du Acequia Real et autres dérivations, a été très fortement médiatisé et altéré par les grands barrages pour la régularisation des eaux de la source (Alarcón et sur le Cabriel, Contreras) et le second barrage de Tous dont la finalité essentielle est l'écrêtement des crues.

De même, les pompages massifs revêtent une importance considérable dans l'Aquifère de la Mancha Oriental depuis 1989, avec une incidence très négative sur la régularisation naturelle du Júcar, son débit de base et la mémoire pluriannuelle.

Mots clés: Régime naturel, altération, grands barrages, pompages.

\section{ABSTRACT}

In spite of the various channels built for the Acequia Real and other derivations, the natural flow of the River Júcar remained fairly constant up until 1957. However, since then, it has been greatly affected and altered by the major reservoirs constructed in order 
to regulate the headwaters (Alarcón; and Contreras, in the river Cabriel) as well as the second dam at Tous, which was essentially built for flood routing purposes.

The mass pumping carried out from 1989 onwards in the Mancha Oriental Aquifer was also highly significant and had an extremely negative effect on the natural flow of the River Júcar, its basic water level and its multi-year memory.

Key words: Natural flow, alteration, major reservoirs, pumping.

Por longitud $(534 \mathrm{~km})$, cuenca $\left(22.145 \mathrm{~km}^{2}\right)$ y aportación media $\left(1.403 \mathrm{hm}^{3}\right.$ en Tous, en régimen natural), el Júcar es el primer río alóctono de la fachada este de España y, tras el Ebro (929 km, $85.997 \mathrm{~km}^{2}$ y $17.967 \mathrm{hm}^{3}$ ), el segundo de la vertiente mediterránea española. Nace, al igual que Tajo, Turia y Cabriel, en el gran nudo hidrográfico de Albarracín, y, con núcleo en la sierra de Tragacete, incluye en su cabecera una porción considerable de la Serranía de Cuenca, relieve cárstico de múltiples resurgencias, que en parte afluyen al Júcar. Gracias a que estas montañas medias funcionan como pantalla orográfica e interceptan corrientes atlánticas perturbadas, sus observatorios más favorecidos rondan los $1.000 \mathrm{~mm}$ de precipitación anual, con máximo invernal y, al menos, una cuarta parte en forma de nieve. En suma, una cabecera bien organizada y abundante, cuyo carácter pluvionival de origen atlántico, con pico de marzo, privaba, en régimen natural, hasta la desembocadura en Cullera.

A diferencia de la subcuenca anterior, el Júcar manchego, capturado por el mediterráneo en el codo de La Roda, apenas recibe tributarios, son pocos y carecen de importancia, en una llanura interminable de precipitaciones inferiores a $400 \mathrm{~mm}$ e irregulares, si bien el extenso acuífero de la Mancha Oriental, suplementado por derrames de los espacios aledaños, asume protagonismo de primer orden para asegurar el caudal de base del río, proporcionarle una notable regulación natural y mejorar sustancialmente su memoria hiperanual.

En el Júcar valenciano, donde la aportación del acuífero del Caroig reviste indudable importancia, se hace bien presente la componente mediterránea, particularmente a través de los diluvios tardoestivales, que han conferido justa celebridad al río por sus colosales aluviones (4-5 de noviembre de 1864 y 20-21 de octubre de 1982, como ejemplos prototípicos). Así pues, contemplada la cuenca en su conjunto, el régimen del Júcar puede y debe ser definido como pluvionival de raigambre atlántico-mediterránea subtropical.

El ritmo natural, que, a pesar de la cuantiosa detracción de la Acequia Real del Júcar y de otras menores (Carcagente, Antella, Escalona, Sueca, Cullera), perduró hasta 1957, año de la entrada en servicio del gigantesco hiperembalse de Alarcón $\left(1.112 \mathrm{hm}^{3}\right.$ ), ha sido profundamente modificado por el acondicionamiento hidráulico y la explotación de sus aguas subterráneas. Es de destacar que, aun con el fuerte desarrollo del regadío propiciado por la conclusión del segundo tramo de la Acequia Real del Júcar a comienzos del siglo XIX y la temprana presencia del aprovechamiento hidroeléctrico (1909), la regulación por embalses es llamativamente posterior a la de otros ríos alóctonos de la fachada oriental de España como Segura y Turia. Baste señalar que en 1933 comenzó el funcionamiento del hiperembalse de Fuensanta $\left(210 \mathrm{hm}^{3}\right)$ en la cabecera del Segura y, tras el paréntesis de la guerra civil, el de Benagéber (228 $\mathrm{hm}^{3}$ ), en el Turia, iniciado en 1933, fue concluido en 1955, mientras Alarcón, como se ha dicho, no lo fue sino en 1957; tras estos desfases, a primera vista sorprendentes, se encuentran la caudalosidad y regularidad muy superiores del Júcar. Pero dicho régimen natural se ha visto intensamente mediatizado y alterado por los hiperembalses para la regulación de las aguas de cabecera (Alarcón y, en el Cabriel, Contreras) la nueva presa de Tous $\left(379 \mathrm{hm}^{3}\right)$, cuya finalidad esencial es la laminación de avenidas, con la adicional y complementaria de remodular, como contraembalse, la turbinación de recursos, sobre todo, durante el invierno, en los saltos hidroeléctricos del Caroig. 
Especial interés reviste la profunda desnaturalización, con grave daño a la regularidad, a la garantía del caudal de base y memoria hiperanual del río, por los bombeos masivos en el acuífero de la Mancha Oriental para la creación de nuevos regadíos de producción subvencionada, con poco futuro, que han pasado de 5.000 ha en 1970 a más de 100.000 en la actualidad; auspiciados por el amparo legal del Real Decreto 950/1989, de 28 de julio, que declaraba de interés nacional la transformación, con aguas del Júcar, de 69.000 hectáreas en La Mancha.

\section{Cabecera bien constituida y abundante: flujo atlántico, relieve y roquedo}

A mediados del siglo XIX, el Diccionario de Madoz proporciona una descripción precisa y sugerente de las fuentes del Júcar, en los términos siguientes: «Las sierras de Albarracín, que por muchas horas se extienden hacia el $\mathrm{O}$ de la c. que las da nombre en la provincia de Teruel, llegan a ramificarse con las de Cuenca, siendo quizás el núcleo de todas ellas la famosa sierra de Tragacete. En este grupo de escarpadas montañas, y dentro de un radio que sin duda no llega á 2 leg., salen como de un abundante depósito, y en diferentes direcciones 4 r. bastante caudalosos que son: el Tajo hacia el NO.; el Guadalaviar o Turia al E.; el Cabriel al S., y el Júcar al SO. Este último... tiene su principal nacimiento en el cerro llamado de San Felipe y sitio denominado Ojuelos de Valdeminguete, en la prov. y part. jud. de Cuenca, térm. jurisd. y al N. de Tragacete. Las abundantes lluvias tan frecuentes en la sierras inmediatas á este r., el derretimiento de las nieves de que la mitad del año se ven cubiertas principalmente aquella parte que con toda propiedad llaman Tierra Muerta, formando muchos y considerables arroyos, aumentan el caudal del Júcar y le hacen casi invadeable á poco trecho de su origen, mayormente en la estación lluviosa. Poco más debajo de su nacimiento y junto al pueblo de Tragacete ...» ${ }^{1}$. Aspectos destacados en el párrafo anterior son la importancia del gran nudo hidrográfico de los Montes Universales de Albarracín y su conexión con la vecina Serranía de Cuenca, el sustancial incremento orográfico de las precipitaciones, la importancia de la nieve y el comportamiento del roquedo calcáreo como almacén y depósito de agua.

En el borde oriental de la Meseta, pertenecientes a la rama castellana de la Cordillera Ibérica, la Serranía de Cuenca y los Montes Universales de Albarracín, estos últimos ya en tierras turolenses, constituyen porción relevante de la mayor divisoria de aguas entre las vertientes atlántica y mediterránea. Las corrientes perturbadas y borrascas atlánticas de componente oeste, al encontrar en su trayectoria hacia el Mediterráneo las susodichas montañas medias, ocasionan precipitaciones sobre las mismas, permitiendo que los observatorios más favorecidos por altitud y exposición totalicen una precipitación media anual de 900-1.000 mm, valores éstos que duplican a los situados al pie de aquéllas, con registros entre 400 y $500 \mathrm{~mm}$. A la pluviometría contribuyen también las precipitaciones mediterráneas, pero de manera secundaria y esporádica, casi siempre en otoño con bajos índices zonales y fragmentación de esta circulación, en situaciones de fuerte inestabilidad atmosférica, con embolsamientos de aire frío en los niveles superiores y aparición en superficie de anticiclones de bloqueo, que sectorial y episódicamente reemplazan la circulación habitual del oeste por levantes o gregales.

Otros datos pluviométricos sobresalientes, indispensables para la caracterización del régimen fluvial, son el carácter habitual de las nevadas - 15 a 20 días - en el largo y frío invierno e innivaciones prolongadas, no tanto como lo eran a mediados del siglo XIX, en

1 MADOZ, P. (1846-1850): Diccionario Geográfico - Estadístico - Histórico de España y sus posesiones de Ultramar, Madrid, IX, pág. 654. 
las postrimerías de la llamada Pequeña Edad del Hielo, pero aún muy considerables, por cuanto los Montes Universales de Albarracín y la Serranía de Cuenca registran temperaturas invernales entre las más bajas de España (Cuenca, $4,4^{\circ} \mathrm{C}$ en enero; por bajo de Albacete, $5^{\circ}$ ), a causa de la conjunción de altitud y, sobre todo, continentalidad, sin moderación marítima atlántica, por la lejanía del océano y la condición maciza de la península ibérica, ni regulación térmica mediterránea, ya que ésta, cuya proyección es de sentido opuesto a la circulación atmosférica del oeste, queda circunscrita a tierras litorales y prelitorales.

En el referido Diccionario de Madoz, al abandonar el Júcar la provincia de Cuenca, se hace constar que «es de curso perenne, y mientras corre por esta prov., poco ó nada se distraen sus aguas para el riego .... ${ }^{2}$, situación que perdura en la actualidad; por ello, el aforo de Alarcón resulta enteramente significativo de la caudalosidad y régimen de la cabecera del Júcar, es decir, de la subcuenca superior o Alto Júcar. Con observaciones desde 1948, la aportación anual media es de 424,9 $\mathrm{hm}^{3}{ }^{3}$, equivalente a un módulo de 13,464 $\mathrm{m}^{3} / \mathrm{s}$, caudalosidad suficiente para que, sin importantes demandas consuntivas, la corriente conserve su carácter permanente, incluso en los episodios de sequía, mitigados por la notable regulación que introducen los acuíferos; de ahí que históricamente se subraye la condición perenne del río desde cabecera.

La abundancia del Alto Júcar, con un caudal relativo de $8,301 / \mathrm{s} / \mathrm{km}^{2}$, el desfase de un par de meses entre los principales accidentes de la curva anual de precipitaciones y los de la de coeficientes mensuales del módulo fluvial, un grado de estacionalidad evidente pero no exagerado y, en suma, un régimen pluvionival de raigambre oceánico-mediterránea subtropical que revela regulación natural y memoria hiperanual, obedecen a la presencia de precipitaciones acrecentadas por el efecto de pantalla de la montaña media sobre el flujo atlántico, con inequívoco máximo invernal, y, en relación con él, la frecuencia relativamente alta de la nieve, e innivaciones duraderas, así como a la elevada infiltración de precipitaciones de intensidad moderada en un roquedo muy permeable, que alimenta acuíferos y nacimientos.

Rasgos destacables de la curva de coeficientes mensuales correspondientes al año hidrológico medio del Júcar en Alarcón son los siguientes: aguas altas de diciembre a mayo, con ápice de marzo, y estiaje que, insinuado casi como punto de inflexión en junio, se acentúa hasta septiembre, resultando todavía los caudales de octubre y noviembre inferiores al módulo. Como se ha dicho, aunque la estacionalidad es marcada, la curva anual de caudales dista de mostrar contrastes similares a los existentes en los ríos mediterráneos autóctonos, ya que el cociente entre las aportaciones medias mensuales extremas (marzo y septiembre) no llega a 4. Sin embargo, es de destacar que la fase con abundancia menor que la media dura seis meses seguidos y apunta ya en junio, desaparecida la nieve y reintegrado a la circulación en superficie el grueso de las precipitaciones invernales infiltradas; resaltemos asimismo la escasa relevancia de las lluvias primaverales y la menor importancia de las tormentas estivales, que hacen del verano la estación más lluviosa en sectores del Alto Turia y Maestrazgo ${ }^{4}$.

A partir de octubre se produce una recuperación moderada del caudal hasta diciembre, y fuerte desde ese mes a enero-febrero, con máximo en marzo, cuando comienza la fusión de las nieves, que prosigue en abril y mayo. Era en estos meses de aguas altas cuando los

2 MADOZ, Op. cit. IX, pág. 655.

3 MARCO SEGURA, J.B. (2004): «Evolución histórica del sistema de aprovechamiento y su impacto sobre el régimen hídrico de los ríos Júcar y Turia», en GIL OLCINA (Coord.): Alteración de los regímenes fluviales peninsulares, Fund. Cajamurcia, pág. 332.

4 MARTÍN VIDE, J. y OLCINA CANTOS, J. (2001): Climas y tiempos de España, Alianza Editorial, pág. 42. 
gancheros aguaban las piezas de pino que habían pasado el invierno encambradas y «purgando» en los entandes o peañas de los llanos de Verdelpino, aguas arriba de la famosa Hoz del Júcar, que, junto con la del Huécar, tributario en cuya confluencia se emplaza estratégicamente Cuenca, constituyen ejemplos prototípicos de estas formas fluviocársticas, tajadas por el río a favor de la caudalosidad, pendiente y, sobre todo, sucesivos hundimientos de cámaras de disolución.

Marco hizo notar que el Júcar es un río con memoria hiperanual ${ }^{5}$, es decir, el significativo retraso de parte del agua caída en reaparecer en el río atempera los episodios de sequía, a costa de prolongar en el tiempo su repercusión; con todo, los periodos largos e intensos de sequía, como por ejemplo los de 1978-82 y 1992-95, dejan profunda huella y mellan la curva de aportaciones anuales en Alarcón.

\section{El Júcar manchego: las descargas copiosas y regulares del acuífero de la Mancha Oriental}

En la provincia de Albacete el río discurre por territorio de morfología muy diferente a la de su cabecera: frente a la anfractuosidad escarpada y bravía de ésta, con altas muelas y profundas gargantas u hoces, la planitud y monotonía de la inmensa llanura que escapa a la vista. Este radical contraste de relieve entre la Serranía de Cuenca y la Mancha se traslada a las redes hidrográficas del Alto Júcar y Júcar Medio, con densa retícula de arroyos afluentes la primera y prácticamente huérfana de tributarios la segunda, con la modesta excepción del Valdemembra, que confirma la regla. Pero lejos de perder caudal, regularidad o memoria hiperanual, el Júcar casi duplica el primero $\left(23,45 \mathrm{~m}^{3} / \mathrm{s}\right.$ en El Molinar) y mejora sustancialmente la regulación natural, merced todo ello a las aportaciones del extenso acuífero de La Mancha Oriental (identificado con el número 29 por el ITGME). En régimen natural, a dichas descargas debía primordialmente el Júcar un llamativo mantenimiento de su caudal de base, al extremo que, sin exageración alguna, se ha podido afirmar que «el Júcar —más allá de las exorbitantes avenidas- era el río más regular en régimen natural de la fachada mediterránea que, sin regulación de embalses, posibilitó la puesta en riego de La Ribera y un sostenido aprovechamiento hidroeléctrico» ${ }^{6}$.

Este vasto acuífero carbonatado de $500 \mathrm{~km}^{2}$, atravesado por el Júcar de norte a sur, tiene sus dos terceras partes en la margen derecha del curso, de forma tal que su sector central dista de éste una treintena de kilómetros, hecho de indudable trascendencia en el ritmo de aparición de estas aguas subterráneas en el Júcar. En esencia, su estructura incluye un banco de calizas cretácicas y jurasicas horizontales, sobre la que descansa una ligera cobertura cuaternaria de arcillas o margas, aunque de espesor local variable; donde éste aumenta, como sucede en sus áreas septentrional y meridional, mengua sensiblemente la permeabilidad, se reduce la infiltración y, por ende, la captación de agua, que, en cambio, suben hacia el entorno de Albacete. El agua recogida por el acuífero no proviene sólo de la precipitación in situ, con valores medios anuales exiguos, por bajo de $400 \mathrm{~mm}$ (Albacete, 366), máximos de primavera (abril, 52) y otoño (octubre, 40), y verano seco (julio, 9), ni de la sola adición de los débitos de pequeños cursos como Lezuza y Jardines que, originados en las sierras subbéticas del suroeste, al llegar al llano se infiltran en su totalidad y desaparecen, sino que recibe considerables aportes laterales.

5 MARCO SEGURA, Op. cit., pág. 332.

6 MATEU BELLÉS, J. (2001): «Aguas continentales», en GIL OLCINA, A. y GÓMEZ MENDOZA, J.: Geografía de España Ariel, pág. 134. 
El recorrido del Júcar por el acuífero de la Mancha Oriental viene a concluir con el de las tierras albacetenses; por ello, el aforo valenciano de Molinar, con restitución de sus datos al régimen natural ${ }^{7}$, permite conocer la decisiva contribución del acuífero al caudal de base y regularidad del río. En este sentido, el análisis comparado de las series de Alarcón y Molinar resulta harto elocuente: así, la superposición de las curvas anuales de coeficientes entre los respectivos módulos mensuales y el anual hace bien patente que la de Molinar es más uniforme, menos accidentada, con tendencia al aplanamiento, los valores extremos, mantenidos en marzo y septiembre, proporcionan un cociente $(2,31)$ sensiblemente inferior al de Alarcón $(3,87)$, con pico culminante y punto mínimo menos pronunciados en la curva.

Como se ha anticipado, el caudal del Júcar, lejos de menguar, experimenta un fuerte aumento, subiendo, en régimen natural, a $23,436 \mathrm{~m}^{3} / \mathrm{s}$, es decir, un incremento de $74,06 \%$ sobre los 13,464 m³/s de Alarcón. La aportación media en Molinar es de 739,9 hm³/año, lo que supone una diferencia positiva de $315 \mathrm{hm}^{3}$ respecto de los 424,9 en Alarcón ${ }^{8}$. Por la regulación del extenso acuífero, mejora también sustancialmente la memoria hiperanual del río, de manera que la serie de aportaciones anuales de Molinar presenta rango de oscilación inferior a la de Alarcón. En suma, tras atravesar la seca Mancha Oriental, el Júcar, en régimen natural, resultaba mucho más abundante y regular. Fueron estas características las que propiciaron la temprana instalación de la central hidroeléctrica de Molinar, con tendido, en 1909, de una línea de 60 kilovoltios y $250 \mathrm{~km}$, la de mayor tensión y longitud existente por entonces en Europa, para transportar la energía producida a Madrid.

\section{Gestación de las grandes avenidas tardoestivales y llano de inundación}

Como se ha reiterado, los caudales mensuales más elevados se deben a precipitaciones invernales, son de raigambre atlántica y, en los aforos de Alarcón, Molinar y también Tous, corresponden a marzo. En cambio, el calendario de lluvias catastróficas muestra clara preferencia por los meses tardoestivales, entre mediados de septiembre y la primera quincena de noviembre, con ápice en octubre, transcurre el periodo de máximo riesgo de las grandes avenidas fluviales, con cuyos desastrosos efectos se ha pretendido imaginariamente relacionar el propio nombre de Xúquer; y ese sí es un rasgo decidida y caracterizadamente mediterráneo.

En la génesis de las mayores crecidas del Júcar aguas arriba de la cerrada de Tous, todas ellas de filiación mediterránea y tardoestivales, asume máximo protagonismo, como superficie alimentadora, el macizo del Caroig y su entorno; así fue en la de 4-5 de noviembre de 1864 y también el 20-21 de octubre de 1982. Integrada por potentes calizas cretáceas horizontales, la extensa plataforma del Caroig, $45 \mathrm{~km}$ de norte a sur, entre las montañas ibéricas y las sierras prebéticas, y 35 de oeste a este, desde las tierras manchegas a la Ribera del Júcar, con altitudes de 800-1.000 m al oeste y 400-500 en el este, ofrece una morfología de mesas o muelas (Bicorp, Cortes de Pallás, Albéitar) entre profundos valles fluviocársticos. Al oeste se abre un estrecho valle desde Cofrentes a Ayora, formado a expensas de un anticlinal fallado, de tectónica diapírica, con relleno mioceno, y drenado por el ReconqueCantaban, que llega al Júcar en Cofrentes, cerca de la confluencia del Cabriel.

Al sureste la plataforma queda parcialmente escindida por la Canal de Navarrés, excavada en un anticlinal fallado de Keuper diapírico. En el borde sur de la plataforma, pliegues y fallas SW-NE, rumbo de la sierra y valle de Enguera, preludian las cercanas sierras prebéticas. A los efectos que ahora interesan, reviste especial interés el borde septentrional del

\footnotetext{
7 MARCO SEGURA, Op. cit. pág. 334.
}

8 MARCO SEGURA, Op. cit. pág. 334. 
macizo, donde por el fondo de un extraordinario y largo congosto de $400 \mathrm{~m}$ de profundidad, con escarpes verticales de $200 \mathrm{~m}$ en algunos sectores, discurre el Júcar, con pendientes del 4 al $6 \%$, hasta 8 en algún punto. Una elevación en masa reciente y el hundimiento litoral, al crear un fuerte desnivel, desencadenaron una erosión remontante muy potente, que permitió al Júcar mediterráneo capturar, mediante un colosal cañón, al Cabriel y, en el codo de La Roda, al Júcar manchego.

Mecanismo no desdeñable de colaboración del Caroig en las peores inundaciones del Júcar es el profundo y largo congosto fluvial citado, que, al evitar el aplastamiento de las ondas de crecida, ha permitido que rompieran, altas y potentes, en La Ribera, el gran llano de inundación holoceno de escasa pendiente $(0,6 \%$ ) y Júcar meadrizante, abierto al Mediterráneo entre la Albufera de Valencia y la Marjal de Xeraco; es de notar, como indica Mateu", que «el Júcar pasa directamente del llano de inundación al mar sin edificar un delta porque los acarreos sólidos a lo largo del Holoceno se han depositado mayoritariamente en el llano de inundación sin llegar al mar ... los sedimentos holocenos han contribuido a modelar una geometría convexa edificada desde el mar hacia el interior de modo que los acarreos medievales y modernos sirven preferentemente para terraplenar la Ribera Alta».

Mateu juzga divisorias relevantes del llano de inundación los abanicos de los ríos Albaida y Magro: «El primero limita un tramo de inundación cóncavo situado aguas arriba de otro convexo... El segundo interrumpe momentáneamente dos tramos convexos. Esta diferencia entre ambos explica que el área de influencia del Magro con el Júcar sea el elemento central para una correcta evaluación hidrogeomorfológica de la Ribera ${ }^{10}$. Se sucederían así tres tramos desde Tous al Mediterráneo.

En la Vallfarta, desde Sumacárcer, aforo famoso de $60 \mathrm{~m}^{3} / \mathrm{s}$ en el I Plan Nacional de Obras Hidráulicas (1933), a la confluencia del Albaida, el Júcar circula por un llano cóncavo de glacis a glacis, perfil que auspicia frecuentes mutaciones laterales de los lechos y la rápida evolución de los meandros; por la derecha llega también el río Sellent. Aguas abajo de la confluencia del Albaida y hasta la del Magro, por la izquierda, el Júcar discurre, por un llano convexo, sobreelevado sobre sus márgenes inundables, de manera que sus aguas desbordadas no pueden retornar al cauce y circulan por los cursos paralelos de Barcheta, a la derecha, y el Río Verde, a la izquierda. Este segundo tramo se ve interrumpido por el estrechamiento cóncavo que sigue el Júcar entre la acera coluvial de su margen derecha y el abanico coluvial del Magro, cuya progradación condiciona la evacuación de las aguas de la Ribera Alta. Sobrepasado este estrangulamiento cóncavo, el llano recobra el perfil convexo hasta el Mediterráneo; esta curvatura explica que, además del débito que mantiene el cauce principal, las aguas desmadradas diverjan, por el norte, entre Sollana y la Montanyeta dels Benissants, hacia la Albufera de Valencia, y, por el sur, hacia la Marjal de Tavernes, para desembocar eventualmente por la Sequiaza-Estany Grau; en suma, como señalara Rosselló, un frente marítimo de inundación extendido prácticamente entre los graos de Valencia y Gandía ${ }^{11}$.

Añadamos, por último, que los ríos Albaida, Sellent y Magro, cuyas contribuciones a la aportación anual media del Júcar revisten escasa importancia, sí cuentan, y mucho, en los grandes aluviones tardoestivales, de característica filiación mediterránea. Una de las pocas opiniones unánimes sobre la avenida de 20-21 de octubre de 1982 señala que su extraordinaria magnitud en La Ribera se debió a la coincidencia de los picos de crecida del Júcar y

9 MATEU BELLÉS, Op. cit. 12, pág. 196.

10 MATEU BELLÉS, Op, cit. 12, págs. 192-193.

11 ROSSELLÓ VERGER, V. Ma . (1983): «La revinguda del Xúquer de 1982 i el desastre de la Ribera (20-21 de octubre de 1982). Una perspectiva geogràfica», Cuadernos de Geografía, 32-33, págs. 213-240. 
de sus tributarios autóctonos, es decir, Albaida, Sellent y Magro, éste en menor medida por la regulación de Forata, aunque desempeñó papel importante en la inundación de Algemesí; tal y como indica Mateu, resulta «probable que los cierres y pantanos hidráulicos fueran el fenómeno característico en las confluencias del Sallent con el Júcar y del Magro con el Júcar: con razón las gentes de los pueblos hablaban del reflujo (regolfe) o que en algunos momentos circulaban contra corriente. Cuestión distinta ocurriría en la confluencia del Albaida con el Júcar: ambos actuaban de vectores cuya resultante se encaminaba desbordada hacia Alberic y el Riu Verd» ${ }^{12}$.

\section{Escorrentía natural del Júcar}

Cuando aún no mediaba el siglo XX, Masachs ${ }^{13}$ pudo analizar un Júcar en régimen casi natural hasta Antella, dado que los embalses entonces existentes en su red fluvial, de estricta finalidad hidroeléctrica y con capacidad máxima de $11 \mathrm{hm}^{3}$ para los de La Toba y Embarcaderos, no introducían regulaciones sustanciales, al tiempo que las detracciones para riego aguas arriba del citado azud resultaban modestas.

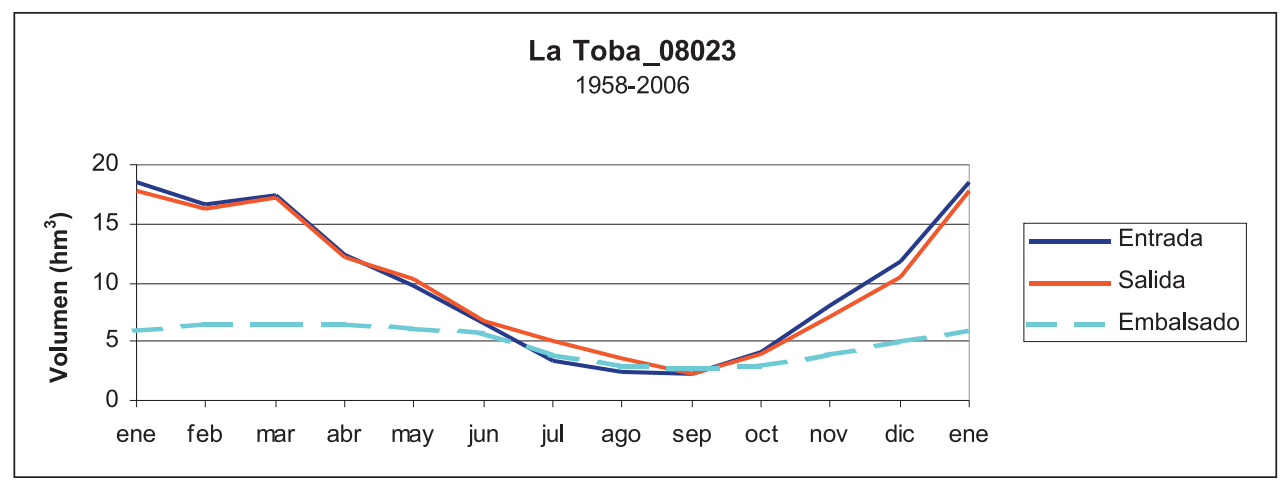

Figura 1. El embalse de la Toba no altera, prácticamente, el régimen de cabecera del Júcar, introduciendo sólo leves correcciones, con la retención de un modesto volumen, para garantizar el funcionamiento de la central hidroeléctrica.

El aforo de Cuenca, con mediciones durante un cuarto de siglo, revelaba una cabecera rica en aguas, relativamente más abundante que las de los otros tres cursos (Cabriel, Tajo, Turia) que irradian como él del gran nudo hidrográfico de los Montes Universales de Albarracín, con un módulo específico de $8,30 \mathrm{l} / \mathrm{s} / \mathrm{km}^{2}$, seguido por el del Cabriel $(6,6)$, su principal afluente, superiores ambos, para superficies vertientes proporcionadas, a los del Tajo $(6,30)$ y Turia $(2,31)$. Antes de la entrada en servicio del hiperembalse de Alarcón (1957), el caudal de base generado en la subcuenca superior dominaba el régimen del Júcar hasta la desembocadura en Cullera. Dicho módulo $\left(11,82 \mathrm{~m}^{3} / \mathrm{s}\right.$, para $1.424 \mathrm{~km}^{2}$, en Cuenca; $15,91 \mathrm{~m}^{3} / \mathrm{s}$, en Olivares, con $3.124 \mathrm{~km}^{2}$ ) es de clara raigambre atlántica, resultante de la intercepción orográfica de flujos perturbados de esa procedencia, que arrastran borrascas del oeste, suroeste y noroeste, primordialmente durante el duro y prolongado invierno, con

12 MATEU BELLÉS, Op. cit. 12, pág. 208.

13 MASACHS ALAVEDRA, V. (1948): El régimen de los ríos peninsulares, Barcelona, Inst. Lucas Mallada (C.S.I.C). 


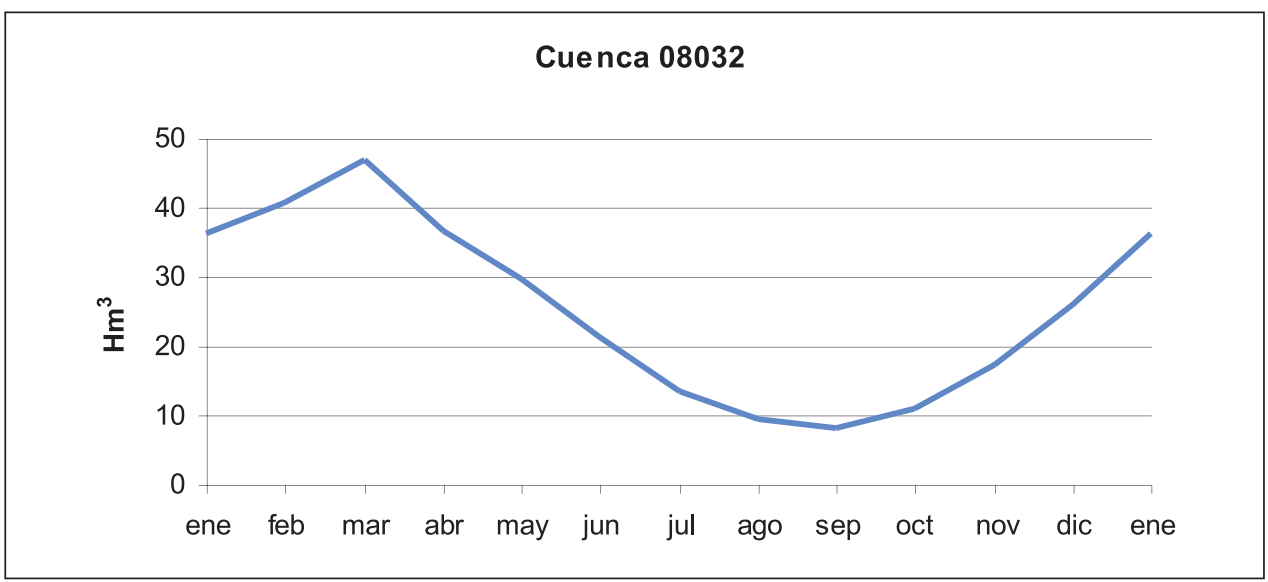

Figura 2. El aforo de Cuenca refleja el régimen natural del Alto Júcar, ya que la modesta incidencia del embalse de La Toba $\left(11 \mathrm{hm}^{3}\right)$ no basta a desvirtuarlo. Hay aguas altas de diciembre a abril y bajas de mayo a noviembre, resultantes de las precipitaciones líquidas y sólidas de raigambre atlántica, fusión de éstas y abundante infiltración cárstica. La demora en la reaparición de los caudales subterráneos ocasiona desfase entre las curvas de precipitaciones y módulos fluviales.

nevadas, muy probablemente, más frecuentes e intensas para esa primera mitad de siglo XX que en la actualidad.

Al dejar atrás las montañas medias conquenses y el incremento en las mismas de las precipitaciones, con reducción de éstas a la mitad, incluso a una tercera parte, en determinadas áreas manchegas, el Júcar a duras penas mantiene el valor del módulo en la estación de Los Nuevecillos, según datos de Masachs ${ }^{14}$, pero el caudal relativo desciende a 3,80 1/s/ $/ \mathrm{km}^{2}$, es decir, el 45,78\% que en Cuenca. El módulo subía a 26,60 m³ en Los Frailes y a 32,83 en Jalance, que suponen aumentos sucesivos de 66,98 y $23,42 \%$ mientras las respectivas superficies vertientes lo hacen en 65,01 y 64,75\%; es de resaltar que el notable ascenso de la abundancia entre Los Nuevecillos y Los Frailes obedece primordialmente a las descargas del acuífero de la Mancha Oriental, entonces prácticamente intacto y hoy objeto de bombeos masivos, en detrimento del caudal, regularidad y memoria histórica del Júcar, para atender en torno a 100.000 hectáreas de regadío, extensión que duplica, a la existente en La Ribera.

Como se ha dicho, el Júcar llevaba en Jalance, con $11.374 \mathrm{~km}^{2}$ de cuenca, un módulo de $32,83 \mathrm{~m}^{3} / \mathrm{s}$, es decir, un caudal relativo de $2,88 \mathrm{l} / \mathrm{s} / \mathrm{km}^{2}$, casi una tercera parte de los 8,30 de Cuenca; por su parte, el Cabriel pasaba con $23,11 \mathrm{~m}^{3} / \mathrm{s}$ por el aforo de Villatoya, para una superficie avenada de $4.490 \mathrm{~km}^{2}$, lo que arroja un módulo específico de $5,14 \mathrm{l} / \mathrm{s} / \mathrm{km}^{2}$, que casi duplica al del Júcar. Aguas abajo de la confluencia, en Sumacárcer, con una cuenca total de $17.603 \mathrm{~km}^{2}$, resultaría, según González Quijano, un caudal medio de $59,70 \mathrm{~m}^{3} / \mathrm{s}$, que Manuel Lorenzo Pardo redondeó en el I Plan Nacional de Obras Hidráulicas (1933), señalando que « el aforo capital es el del Júcar en Sumacárcer. Arroja un caudal de 60 metros cúbicos por segundo, equivalente a un volumen de 1.913 millones de metros cúbicos anuales, de los cuales más de una mitad es derivada por la antigua e importantísima Acequia Real del Júcar. Según puede verse en el gráfico (se refiere al de la pág. 161), la cabecera

14 MASACHS, Op. cit. pág. 448. 
del río, o sea el tramo anterior a Cuenca, contribuye con 11 metros cúbicos por segundo y 363 millones, y el Cabriel, con 20 metros cúbicos por segundo y 623 millones» ${ }^{15}$. Esos míticos $60 \mathrm{~m}^{3} / \mathrm{s}$ son hoy una cifra alejada de la realidad por las fortísimas extracciones en el acuífero de la Mancha Oriental. En la actualidad, la situación del acuífero es tal que, lejos de alimentar al Júcar como hizo antaño, con aportación media en torno a $350 \mathrm{hm}^{3}$ anuales, al producirse extracciones del mismo por encima de $320 \mathrm{hm}^{3}$, máximo autorizado en el Plan Hidrológico de la Cuenca del Júcar (1998), especialmente en años secos, en los que han llegado a sobrepasarse los $400 \mathrm{hm}^{3}$, entonces el sentido del flujo se invierte, de manera que los caudales procedentes de la subcuenca superior enjugan el déficit generado en el acuífero por sobreexplotación; así pues, no resulta aventurado estimar que el umbral establecido por el indicado Plan Hidrológico ha sido rebasado algún año en no menos de $100 \mathrm{hm}^{3}$.

En síntesis, el régimen natural del Júcar en Tous refleja la condición de encrucijada meteorológica de la península ibérica, y lo hace del modo siguiente: el caudal de base, generado en los Montes Universales de Albarracín, Serranía de Cuenca y por las descargas del acuífero de la Mancha Oriental, a favor de la circulación general atmosférica del oeste, posee raigambre atlántica; en cambio, los potentes aluviones tardoestivales u otoñales reciben agua mediterránea, aportada por vientos de componente este (levantes, gregales); y, por último, las aguas bajas del estío y, casi siempre, las sequías guardan estrecha relación con la subsidencia subtropical.

Fenómeno muy destacable en el Júcar son sus avenidas, pero éstas responden a dos tipos de origen y entidad bien diferentes. Las de cabecera, aun antes de la entrada en servicio del hiperembalse de Alarcón (1957), no han revestido nunca peligrosidad para la Ribera, ya que alcanzaban dicho llano de inundación aplastadas por el largo recorrido; así pues, no cabe imputarles responsabilidad alguna en los serios daños sufridos repetidas veces por el azud de Antella, hasta precisar en varias de ellas reconstrucción total. Causantes de estos destrozos y de los terribles desbordamientos en La Ribera han sido, en cambio, las desencadenadas por copiosos e intensos aguaceros tardoestivales u otoñales de raigambre mediterránea. Son las riadas que han proporcionado al río triste celebridad; en esta categoría entran, para los dos últimos siglos, las de 1805, 1834, 1864, 1916, 1919, 1923, 1982, 1987 y 1997, esta última conjurada por las presas de Tous II y Escalona.

Llamativamente Masachs no valora en debida forma las fabulosas llenas mediterráneas del Júcar, y emplea en sus análisis los aforos de Villatoya para el Cabriel y Confluencia en el Júcar, y obviamente el segundo no es el más indicado y expresivo, por cuanto su situación, al comienzo de la cuenca valenciana, sólo le permite reflejar mínimamente los referidos episodios. En consecuencia, las estaciones de medida indicadas muestran aluviones, en términos absolutos y relativos, notoriamente inferiores a los registrados en Tous y Sumacárcer.

En los tres lustros de 1915-29, el Cabriel rebasó los 300 m³/s en Villatoya tres veces, una en diciembre y dos en enero; por su parte, el Júcar, en Confluencia, excedió los $500 \mathrm{~m}^{3} / \mathrm{s}$ en dos ocasiones (octubre y diciembre), con máximo de $1.685 \mathrm{~m}^{3} / \mathrm{s}$ para la primera, debido a que no se trata ya de una crecida gestada en la lejana cabecera sino de la fase inicial de otra donde el macizo de Caroig, con diluvio mediterráneo, asumió señalado protagonismo; con todo, cifra todavía muy por bajo de las correspondientes a los colosales aluviones de la Ribera que, en casos extremos, alcanzan puntas por encima de $10.000 \mathrm{~m}^{3} / \mathrm{s} \mathrm{y}$, excepcionalmente, de 15.000. Al comentar los datos de crecidas, afirma literalmente Masachs que

15 I PLAN NACIONAL DE OBRAS HIDRÁULICAS, I, pág. 654. 
«estos cuadros permiten deducir, en cuanto a las fechas de máxima frecuencia de avenidas, que éstas son las mismas para el Júcar y el Cabriel que no en balde tienen origen en el mismo macizo montañoso y un mismo tipo de alimentación; es la dominante la estación primaveral, sigue luego un mes de junio asimismo con cierta frecuencia de crecidas, y, por fin, un período otoñal con alguna crecida importante, pero en menor número que en primavera...En el Júcar y el Cabriel las crecidas de primavera corresponden a la suma de lluvias de la estación más la fusión nival; las de junio, a la lluviosidad tormentosa de este mes, y las otoñales a la lluviosidad de dicha época» ${ }^{16}$.

Con el esquema interpretativo ya propuesto para el régimen del Júcar, que reconoce como primordialmente atlántico el caudal de base, mediterráneos los diluvios tardoestivales u otoñales y subtropicales verano seco y, casi siempre, las sequías, la justificación de los desbordamientos del Júcar hubiera sido muy otra, al hacerse patente que Masachs buscó el mecanismo esencial de las riadas del Júcar en el área que proporciona el caudal de base, es decir, en la subcuenca superior, sin discernir que el origen de los diluvios causantes de las peores inundaciones de la Ribera es mediterráneo, y que éstas se generan en el macizo de Caroig y resto de la cuenca valenciana del Júcar. En suma, es indispensable la distinción entre las crecidas de cabecera y los fabulosos aluviones de raigambre mediterránea y adscripción valenciana.

Las avenidas de cabecera vienen motivadas por aguaceros copiosos e intensos vinculados, en su mayoría, a frentes fríos anabáticos de borrascas atlánticas con permanencia superior de lo habitual sobre la subcuenca superior o a fusiones rápidas de la nieve acumulada con advecciones de aire polar o ártico, hidrometeoro éste más frecuente en el pasado, particularmente en la llamada Pequeña Edad del Hielo, tal y como, a pesar que dicho período se da para entonces por concluido, refleja todavía Madoz en los términos siguientes: «Las abundantes lluvias tan frecuentes en las sierras inmediatas á este río, el derretimiento de las nieves de que la mitad del año se ven cubiertas, principalmente aquella parte que con toda propiedad llaman Tierra Muerta, formando muchos y considerables arroyos, aumentan el caudal del Júcar y le hace casi invadeable á poco trecho de su origen, mayormente en la estación lluviosa ${ }^{17}$. En alguna ocasión, la llena es fruto conjunto de la fusión de nieves y aguacero intenso. Por último, durante verano no faltan fenómenos convectivos en los Montes de Albarracín y Serranía de Cuenca, resueltos a veces en intensos chubascos tormentosos, que ocasionan crecidas e inundaciones.

Como se ha dicho, incomparablemente más caudalosas y devastadoras son las grandes crecidas de filiación mediterránea, gestadas fundamentalmente en la porción valenciana de la cuenca del Júcar, es decir, desde el macizo o plataforma del Caroig inclusive. Las situaciones y mecanismos atmosféricos causantes, combinados con aire supramediterráneo -en última instancia este mar continental, gigantesco reservorio de aguas y calorías, es el responsable - , son diversos y no se limitan, en modo alguno, a los procesos de «gota de aire frío»; añadamos, cuando menos, depresiones aisladas en niveles superiores, vaguadas meridianas o retrógradas, sistemas convectivos de mesoscala, desarrollos ciclogenéticos, algunos frentes fríos anabáticos de ciclones extratropicales y hasta, en determinadas circunstancias, la convección forzada, impuesta por el relieve a un flujo de muy alta humedad específica.

La curva de coeficientes muestra aguas bajas durante cinco meses, de mayo a septiembre, con mínimo, por bajo de 0,5 , en julio y agosto; fruto todo ello de la hegemonía esos meses de subsidencia y altas presiones subtropicales, con enrarecimiento de las borrascas atlánti-

16 MASACHS, Op, cit., pág. 451.

17 MASACHS, Op. cit., IX, pág. 654. 
cas, que apenas se dejan sentir en la cuenca, sin que basten, en modo alguno, a enjugar ese déficit de precipitaciones las esporádicas tormentas convectivas en las áreas montañosas. Hagamos notar asimismo que, a pesar de una regularidad superior a la de otros cursos alóctonos de la fachada este de España, como Segura o Turia, y de la memoria hiperanual del río, los estiajes se agudizan con ocasión de los períodos de sequía, cuya filiación es asimismo subtropical. Un buen ejemplo proporciona la dura sequía de 1993-96, con serios problemas en el verano de 1994, y primavera-verano de 1995, cuando llegó a plantearse que no resultaría posible «omplir la marjal d'Algemesí» para la siembra, en mayo, del arroz, e incluso llegó a considerarse la posibilidad de que resultara necesario negociar o, en caso negativo, expropiar, la reserva de $40 \mathrm{hm}^{3}$ concedida para la explotación del complejo hidroeléctrico de Cortes-La Muela.

Es de notar que históricamente la demanda de agua para riego en La Ribera ha profundizado y endurecido las estiajes, en particular desde la construcción de la Real Acequia de Alcira y más aún con su prolongación por la Acequia del Nuevo Proyecto o del Duque hasta Albal, convertida en la actual Acequia Real del Júcar. Los problemas de escasez de agua, a los que alude explícitamente Madoz, se producían, en un río de aguas fluyentes, sin regulación artificial alguna, debido a que la máxima demanda de caudales se producía, y todavía ocurre, aunque en menos proporción, durante el verano, para atender balsas de arroz y maizales, al ser estos dos cereales de verano los cultivos de más superficie en La Ribera hasta mediados del siglo XX, cuando la vigorosa expansión de los cítricos motivaría el fuerte retroceso de ambos. La diacronía de las curvas de coeficientes resulta muy expresiva, permitiendo una clara distinción entre Ribera Alta, donde la presencia del arrozal queda restringida a la Marjal d'Algemesí, en rápido retroceso, y la Ribera Baja, donde los arrozales cuentan su mayor superficie de siembra en el término de Sueca. Factor asimismo negativo, con incidencias en el período de aguas bajas, es el bombeo masivo en el acuífero de la Mancha Oriental.

Tal y como se ha indicado, las actuaciones hidráulicas encaminadas al control e incremento de las disponibilidades hídricas y defensa de las poderosas avenidas del Júcar han modificado sustancialmente su régimen natural, con una distinción esencial entre aguas fluyentes y reguladas. Con la primera situación, que perduró hasta la entrada en servicio del hiperembalse de Alarcón el año 1957, puesto que los reservorios construidos hasta entonces en la red fluvial, dada su relativa modestia, no alteraban de manera significativa el ritmo natural, las derivaciones para riego exageraban y profundizaban los estiajes. Sin duda, el ejemplo prototípico era el aforo de Cárcer, aguas abajo del azud de Antella y de la copiosa sangría de la Acequia Real, que, respecto de la estación anterior de Sumacárcer, mostraba, para un período de 17 años, una reducción del módulo del 52,23\%, es decir, de $59,7 \mathrm{~m}^{3} / \mathrm{s}$ a 28,52 , mientras el coeficiente de agosto pasaba de 0,55 a tan sólo 0,14 ; a este respecto, Masach indicaba que «en Cárcer la curva (de coeficientes) presenta un aspecto notablemente diferente del de la curva de Sumacárcer...Dicha curva ostenta la poderosa acción de la Acequia Real que se lleva a los campos, en las épocas de máximo riego, buena parte del pico primaveral pluvio-nival y casi todas las aguas estivales y deja casi en seco el río, mientras en invierno, con dotación incompleta, a causa de la menor necesidad del riego, no deja sentir tan fuertemente su acción sobre él» ${ }^{18}$.

En 1948 el propio Masach, refiriéndose a la incidencia de la acción humana en el Júcar, escribía: «Las principales áreas regadas son la Vega de Cofrentes y La Ribera. La primera es relativamente reducida y se extiende alrededor de la confluencia del Júcar y el Cabriel; 
pasado luego el angosto cañón que por Cortes de Pallás llega hasta Tous, se ensancha el valle y empiezan los riegos con acequias derivadas del Júcar, de las cuales es la principal la Acequia Real, con toma de aguas en Antella. Con una dotación aproximada de $26 \mathrm{~m}^{3} /$ seg riegan unas 14.000 hectáreas; enlaza La Ribera con la Huerta de Valencia. Abajo del azud de Antella son acequias importantes las de Cortes, que riega unas 400 hectáreas; las de Sueca, aguas abajo de Albalat, que irrigan unas 6.500 hectáreas, y las de Cullera, que surten de agua a unas 3.500 hectáreas. Además de estos riegos en el valle principal, son ampliamente nutridos los de los valles del Escalona, Sellent, Montesa, Albaida, Clariano y Rambla de Algemesí o tramo final del Magro. Ninguno de los riegos citados apenas tiene hasta el día obras de regulación,... Proyectado para la regulación de los riegos de La Ribera, el pantano de Alarcón, de 700.000.000 de $\mathrm{m}^{3}$ de capacidad, se halla actualmente en construcción. El régimen del Júcar se ve, por lo tanto, poco afectado por los riegos dada la poca importancia de las obras de regulación hasta el momento construidas, y solamente se resiente, a partir de Antella, por las fuertes sustracciones de elemento líquido que exigen las fértiles llanuras de La Ribera.

Las obras de defensa y desagüe hoy día existentes no afectan al régimen del río...» ${ }^{19}$.

Una década después, con el funcionamiento del hiperembalse de Alarcón, que gobierna la subcuenca superior, cambió por completo la situación. De todo ello se hizo eco, el año 1967, Pérez Puchal en los términos siguientes:» Las curvas que representan las medias mensuales de los once años que van de 1954-55 a 1964-65 son muy elocuentes cuando se comparan con las elaboradas por Masachs.

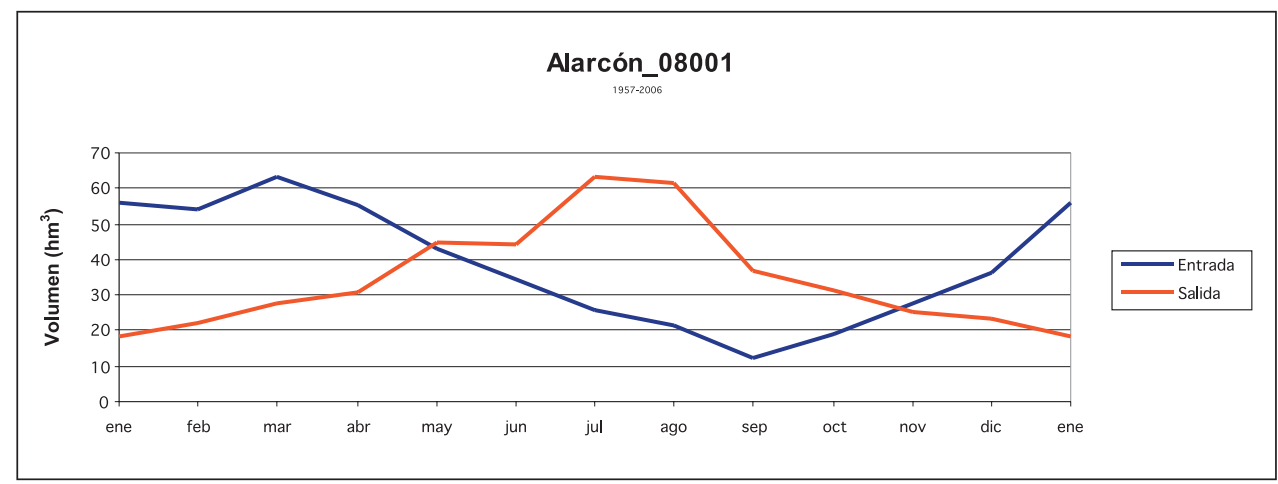

FIGURA 3. Los fuertes desfases entre los volúmenes mensuales medios de entradas y salidas de Alarcón (1957-58 a 2004-05) constituyen la causa primordial de la radical alteración del régimen natural del Júcar, con inversión de las curvas anuales de caudales o coeficientes, ya que el periodo de menores entradas, mayo-noviembre, viene a coincidir con el de mayores salidas por la fuerte demanda agrícola; sucede, en cambio, a la inversa en los meses de diciembre a abril.

En Cuenca, la diferencia es insignificante: sigue habiendo aguas altas de diciembre a abril y bajas de mayo a noviembre, con un máximo en marzo y un mínimo en agosto y septiembre... En cambio, en Alarcón y Los Frailes la influencia del pantano de Alarcón se manifiesta: el régimen se ha invertido. En tanto que en Olivares (1918 a 1929) los meses de febrero a mayo y diciembre eran de aguas altas, reproduciendo el régimen pluviométrico, ahora lo están de mayo a septiembre, con máximos en julio-agosto y bajas de octubre a

19 MASACHS, Op. cit., pág. 447. 
marzo, con mínimo en enero» ${ }^{20}$. La alteración del régimen natural se intensificó y generalizó con la regulación por Contreras de la cabecera del Cabriel, y la serie de presas para la defensa de avenidas.

Tras la colosal crecida del Júcar de 20-21 de octubre de 1982, con rotura de la primera presa de Tous $\left(50 \mathrm{hm}^{3}\right)$, la construcción de la segunda $\left(379 \mathrm{hm}^{3}\right)$ y de otras en los ríos Escalona (Escalona) y Albaida (Bellús) para laminación de avenidas, con obras de defensa en el lecho ordinario del Júcar por La Ribera, la curva de coeficientes quedaba enteramente desnaturalizada e invertida, ubicándose las aguas altas en primavera-verano, cuando mayor resulta la demanda agrícola, con pico en julio, y las bajas en otoño-invierno, con mínimo de octubre antes de la gran riada de 1982; además, el control de desbordamientos ha ganado mucho en eficacia, tal y como se puso de manifiesto el 30 de septiembre de 1997.

Históricamente, los peores desbordamientos del Júcar en La Ribera han sido ocasionados por la conjunción de avenidas de enormes proporciones en el río, gestadas en el macizo del Caroig, y fabulosas llenas en sus afluentes Escalona, Sellent, Albaida y Magro, que ofrecen comportamientos torrenciales con ocasión de aguaceros copiosos e intensos; añadamos también que sus sucesivas desembocaduras en el Júcar se producen en un tramo de menos de $30 \mathrm{~km}$, sincronizando y acumulando peligrosamente, en estos casos, sus desaforadas aportaciones.

Las mayores avenidas del Júcar de que hay noticia histórica son las de 4-5 de noviembre de 1864 y 20-21 de octubre de 1982, mientras las más reciente se produjeron los días 3-4 de noviembre de 1987 y 30 de septiembre de 1997. Todas ellas poseen filiación mediterránea y responden a diluvios otoñales sobre la subcuenca inferior o valenciana. Por su parte, los dos aluviones excepcionales de 1864 y 1982 corresponden al mismo modelo de riadas, iniciadas en el macizo de Caroig y muy potenciadas por las aportaciones de los ríos Albaida, Sallent, Escalona y Magro; además, en ambas intervinieron causas de agravamiento adicionales: en la primera, una gran maderada de no menos de 60.000 piezas que, a partir de Cortes de Pallás, a modo de poderosos arietes destructores, arruinaron Millares, Tous y los azudes de Escalona y Antella, y luego, «impelida la corriente del Júcar por el Sallent y el Albaida, se desviaron las maderas hacia Alberique y Masalaves...El río de los Ojos, y principalmente la rambla de Algemesí que había roto varios malecones ó motas...rechazaron la mayor parte de las maderas hacia la corriente anormal de Moncada y los obligaron a cruzar las partidas de arrozales de la derecha del Júcar. Por esta vía fueron al mar, ...» ${ }^{21}$. Centrada en el problema de las maderadas, la Comisión encabezada por el inspector general de $2^{\mathrm{a}}$ clase del Cuerpo de Ingenieros de Montes Miguel Bosch y Juliá no entró en estimaciones de agua precipitada y caudales. Pero si las realizó la Comisión de Ingenieros de Caminos dirigida por Gómez Ortega, con la conclusión básica que: «En la crecida que tuvo lugar en el Júcar el día 4 de noviembre se combinaron varias causas a la vez, $1^{\text {a }}$ : la grande extensión en que cayó la lluvia. $2^{\mathrm{a}}$ : su duración. $3^{\mathrm{a}}$ : su intensidad en todas partes que, según se ha visto en Carcagente, donde no fue más notable que en otro punto de la cuenca, llegó a la considerable altura de 0,302 en treinta y tres horas. $4^{\mathrm{a}}$ : la especialmente extraordinaria que alcanzó en el partido de Ayora y en el de Enguera». A pesar de que no se disponía más que de un dato pluviométrico — los $302 \mathrm{~mm}$ en 33 horas observado por el Padre Bodí en Carcagente-, se calculó el agua precipitada en $1.444 \mathrm{hm}^{3}$ y en 1.083 la evacuada, con una punta de avenida de $9.117 \mathrm{~m}^{3} / \mathrm{s}$ tras la confluencia del Magro; sin embargo, este caudal debió parecer corto, observando que «es de creer, con fundamento, que aún los 12.243

20 PÉREZ PUCHAL, P. (1967): «Los embalses y el régimen de los ríos valencianos», Estudios Geográficos, 107, págs. 149-196.

21 BOSCH Y JULIÁ, Op. cit., pág. 388. 
metros cúbicos obtenidos sin tener en cuenta la absorción de los terrenos, es aún menor que la cantidad de agua que iba al mar en el máximum de la avenida $»^{22}$.

Casi 118 años después, los días 20 y 21 de octubre de 1982, se abrieron las cataratas del cielo sobre la cuenca valenciana del Júcar, la porción genuinamente mediterránea de la misma, y el Júcar registró un aluvión colosal, de entidad comparable al de 4 de noviembre de 1864. Pero la laxitud de la red pluviométrica y la precariedad de la información hidrológica, con la rotura de Tous por medio, no propiciaron el acuerdo sino la discrepancia en la estimación de caudales: así, el Centro de Estudios Hidrográficos concluye que la punta máxima natural a la entrada del embalse de Tous, alcanzada a las $0.00 \mathrm{~h}$. del día 21 , fue de $7.170 \mathrm{~m}^{3} / \mathrm{s}$; en cambio, ICONA obtuvo datos muy superiores, aunque francamente discutibles, de $10.643 \mathrm{~m}^{3} / \mathrm{s}$ en Millares y 14.395 para Tous ${ }^{23}$. Mateu destaca que «si la inundación de 1864 fue asumida por los habitantes de la llanura como «la mayor de la historia», la de 1982 no ha sido percibida así y buena prueba de ello es el término popular-pantanada- acuñado para referirse a ella ... Sin duda, caudales inferiores a los circulados en noviembre de 1864 han ocasionado en octubre de 1982 pérdidas económicas muy superiores porque el Júcar ha encontrado un espacio donde parte de los nuevos elementos paisajísticos se han localizado en el supuesto que no se repetirían los perímetros históricamente anegados ... Desde 1864 a 1982, la Ribera ha conocido una radical transformación en la utilización humana del llano de inundación» ${ }^{24}$. En 1982, la rotura de la presa de Tous sumó sus efectos a los gravísimos de la colosal crecida, que, a tenor del informe elaborado por ICONA ${ }^{25}$, y de conformidad con el Centro de Estudios Hidrográficos, habría alcanzado caudales punta de $10.643 \mathrm{~m}^{3} / \mathrm{s}$ en Millares, 14.395 en Tous y 15.888 en el Puente de la Casa de Paula (Alberique).

Para la descripción de las catastróficas precipitaciones de 3 de noviembre de 1987 sobre La Safor, que afectaron asimismo a las cuencas de los ríos Albaida, Sellent, Verde y Magro, no bastan los verbos diluviar o jarrear, cuya acepción común es la de llover copiosamente, lo hizo a mares, se abrieron las cataratas del cielo, al extremo que el observatorio de Oliva registró $817 \mathrm{~mm} / 24$ horas, máximo español de la serie 1961-90, con la particularidad que la práctica totalidad de dicha altura se acumuló en no más de seis horas. Protagonismo esencial en este episodio cupo a aire tropical continental en origen que, inserto en una vasta construcción depresionaría que desbordaba el Mediterráneo hasta el Sahara, efectuó un prolongado viaje de ida y vuelta sobre dicha superficie marina y enjugó su déficit hídrico, alcanzando la fachada este de España mutado en aire mediterráneo, cálido y con elevada humedad específica, sumamente inestable, capaz de evolucionar desde muy escasa altitud con reducido gradiente pseudodiabático y, disparado en la vertical por las montañas costeras, alcanzar el nivel dela tropopausa, con generación de gigantescas torres nubosas, colosales cumulonimbos de $10 \mathrm{~km}$ de desarrollo. El gran responsable de esta anegación en La Ribera, menor que la de 20-21 de octubre de 1982, no fue el Júcar, con punta de 1.300 $\mathrm{m}^{3} / \mathrm{s}$, en contraste con los 3.000 a que subió el río Albaida; muy considerables resultaron también los picos de los ríos Sallent, Verde y Magro, con caudales máximos de 800, 500 y $800 \mathrm{~m}^{3} / \mathrm{s}$ respectivamente.

22 GÓMEZ ORTEGA, J. (1866): Estudio de las inundaciones del Júcar por los ingenieros de caminos, canales y puertos, Valencia, texto inédito, Biblioteca de la Confederación Hidrográfica del Júcar, apud MATEU BELLES, J. (1983): «La riada del Júcar y sus efectos en la Ribera», Estudios Geográficos, 170-171, pág. 207.

23 ROSSELLÓ VERGER, V.M ${ }^{\mathrm{a}}$. (1983): «La formación de la riada del Júcar aguas arriba de Tous», Estudios Geográficos, 170-171, pág. 182.

24 MATEU BELLÉS, J. (1983): «La riada del Júcar y sus efectos en la Ribera», Estudios Geográficos, 170-171, págs. 210-218.

25 ROSSELLÓ VERGER, V. M (1983): «La formación de la riada del Júcar (20/21 oct. 1982) aguas arriba de Tous», Estudios Geográficos, 170-171, págs. 171-186. 
Transcurridos casi diez años, un poderoso desarrollo ciclogenético, que conjugaba aire cálido y de fuerte relación de mezcla en superficie y embolsamiento de aire muy frío en altitud, con la subsiguiente exageración de gradiente real y acusada inestabilidad, descargó, el 30 de septiembre de 1997, una mortífera tromba sobre la ciudad de Alicante y, por la tarde, alcanzó las cuencas de los ríos Escalona, Albaida, Sellent y Verde. Las presas de Escalona y Tous laminaron sin dificultad la crecida del Júcar, que, aguas abajo de ésta, sólo se hizo patente por la llena del Sallent, no regulado, a la que se sumó un pico de 865 $\mathrm{m}^{3} / \mathrm{s}$ del Albaida, controlado parcialmente por la presa de Bellús. En este caso, merced al dispositivo de defensa de avenidas ejecutado a partir de las inundaciones de 1982 y 1987 , la de 1997 quedó localizada en 40 km², desde la confluencia del Albaida con el Júcar hasta la desembocadura del río Verde.

\section{Desnaturalización del régimen fluvial por acondicionamiento hidráulico y explotación de acuíferos}

La demanda y consumo de agua más cuantiosos en el Júcar corresponden, con gran diferencia, al uso agrícola, desde la conquista cristiana a la actualidad. En efecto, la primera infraestructura hidráulica importante en el Júcar se debe a Jaime I, que ordenó la construcción de la denominada Real Acequia de Alcira, iniciada el año 1239, con toma del río en Antella; el canal debía llegar al barranco de Catarroja y luego unir sus aguas a las del Turia, para beneficiar a las tierras de su margen derecha, pero no alcanzó sino Algemesí; su prolongación fue acometida, a partir de 1761, por el duque de Híjar, invocando el privilegio otorgado el 16 de enero de 1404 por el rey Martín el Humano ${ }^{26}$ y con la finalidad última de procurar riego a su baronía de Sollana y a todas las tierras que atravesaba hasta allí mediante el cobro de la vigésima parte (vintena) de las cosechas.

El azud de Antella ha sido arruinado varias veces por las furiosas avenidas del Júcar, y rehecho otras tantas; una de ellas en 1835, cuando se procuró a la presa gran solidez, aunque sería nuevamente dañada por las terribles crecidas de 4-5 de noviembre de 1864 y 20-21 de octubre de 1982. Desde Antella, «este larguísimo canal corre ... para atravesar los térm. que fertiliza hasta llegar al de Algemesí, en cuyo boquete o fesa llamada de Cotes termina la primitiva acequia; y riega los térm. de los pueblos de Antella, Gabrda, Alberique, Benimuslem, Puchol, Alcira, Algemesí, Alcudia, Guadasuar, Montortal y Masalavés, que forman la ant. Comunidad de regantes, y como agregados a ella los de Sollana y Albalat de Pardines. En dicho punto de la fesa de Cotes .. están grabadas en piedra las armas del rey D. Jayme, como señal del fin y complemento de la tan laudable empresa que acometió. En este punto empieza la acequia del Nuevo Proyecto, ó sea continuación de la anterior, á cargo del duque de Híjar; fertiliza los térm. de Alginet, Trullás, Alcaicia, Torre de Romaní, Almusafes, Benifayó, Espioca, Silla, Picasent, Alcacer, Beniparrell, Alfal y Catarroja ${ }^{27}$.

Existe la idea muy generalizada y, sin embargo, errónea que, desde la terminación del segundo tramo de la Acequia Real, a comienzos del siglo XIX, la Ribera del Júcar habría dispuesto de manera continua, salvo sequías excepcionalmente duras, de toda el agua necesaria. Sin embargo, multitud de testimonios convencen de lo contrario; así, por ejemplo, el Diccionario de Madoz, casi medio siglo después de concluida la Acequia del Proyecto o del Duque, alude de forma reiterada a problemas de escasez de agua, en los términos siguientes: «En el año 1764 se asegura que de las aguas de esta acequia se regaban cerca

26 MADOZ, Op., cit., I, pág. 450.
27 MADOZ, Op. cit., IX, págs. 654. 
de 67.000 fan. de tierra ..; y sin embargo esto ha variado en tal grado desde aquélla época, y varía tanto continuamente, que es imposible presentar sobre ello un cálculo exacto; más á pesar de todo, bien puede decirse que las aguas de este hermoso canal riegan sobre 170.000 hanegadas por un cálculo aproximado, en esta forma: 90.000 pertenecientes á la ant. Comunidad de regantes, y las demás á la del Nuevo Proyecto, debiéndose advertir que en un año regular, sólo pueden regarse 120.000, y esta escasez es la causa de los disturbios que todos los años se mueven por el riego: algo más de la mitad de estas tierras son arrozales, y las demas huerta» ${ }^{28}$. Y, más adelante, se añade: «La escasez de agua, la siempre creciente necesidad de los pueblos por haber hecho de regadío muchas tierras que antes eran de secano, y convertido en arrozales más terreno del que el duque podía regar con la acequia de su proyecto; el haber abierto las grandes de Escalona y Carcagente, y otras causas unidas a éstas, son un manantial perenne de disputas y reñidas contiendas entre todos los partícipes de las aguas del Júcar, existiendo continuamente expedientes en que cuestionan sus derechos» ${ }^{29}$.

Todo hace pensar que el año hidrológico común o normal conocía en la Real Acequia de Alcira y, por ende, en la Ribera dos periodos muy diferentes por lo que se refiere a demanda de agua para riego y conflictividad, dado que las aguas altas invernales (diciembre-abril) coincidían con la época de menores necesidades del regadío, mientras las aguas bajas estivales lo hacían con el de máxima petición no sólo de la huerta sino, sobre todo, de los arrozales, entonces cultivo básico tanto en la Ribera Alta como en la Baja.

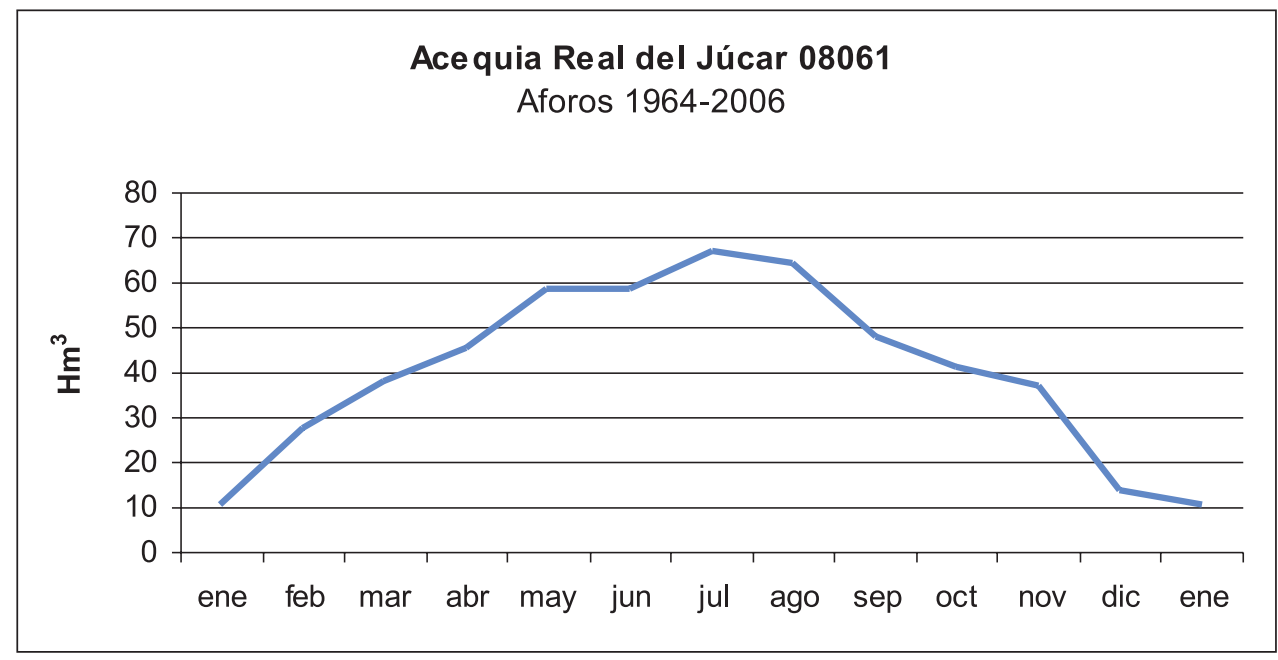

FiguRa 4. El aforo de la Acequia Real del Júcar refleja la evolución anual del consumo agrícola de agua en su demarcación, con máximo de mayo a junio, al sumarse todavía con fuerza, durante el periodo considerado, a las necesidades de los cítricos las del arrozal entre mayo y agosto, si bien en los últimos años dicha demanda se ha reducido sensiblemente por el retroceso de este cultivo.

Con regulación natural y memoria interanual, merced a los acuíferos de la Mancha Oriental y del Caroig, notoriamente superiores a las que presentan los restantes ríos alóctonos de la fachada este de España, el régimen del Júcar no fue modificado por grandes presas hasta

28 MADOZ, Op. cit., I, págs. 450.

29 MADOZ, Op. cit., I, págs. 450. 
mediados del siglo XX, con la entrada en servicio, el año 1957, del hiperembalse de Alarcón $\left(1.112 \mathrm{hm}^{3}\right)$, que controla las aguas de cabecera y el conjunto de la cuenca conquense o alta. El evidente desfase cronológico, cinco lustros, respecto del Segura (La Fuensanta, 1930-33) de la primera gran actuación hidráulica para incrementar disponibilidades en el periodo de aguas bajas, que coincide con la máxima demanda para riego en La Ribera, y almacenar reservas en previsión de años secos, obedece a las mencionadas ventajas del Júcar, pero asimismo a una actitud renuente y nada propicia de sus usuarios a la realización estatal de embalses por el Estado, por el deseo de evitar la intervención de éste en los regadíos históricos o, desde comienzos de la indicada centuria, en los aprovechamientos hidroeléctricos; de esta realidad se hizo eco el I Plan Nacional de Obras Hidráulicas (1933) en los términos siguientes: «La División, en tanto, ha propuesto muchos estudios y ha realizado algunos que, como dijimos, pueden ser considerados como básicos. Todos tienden a regularizar las corrientes principales y a ampliar los caudales medios aprovechables mediante retenciones en lugares superiores y adecuados. Se proyectó seriamente el pantano de Benageber (hoy Blasco Ibáñez), y gracias a ello ha podido ser iniciada su construcción en fecha reciente, sirviendo de base a la regulación del Turia; se han estudiado igualmente los de Marqués, Domeño y Loriguilla, como se hubieran estudiado los de Alarcón, Enguidanos y Tous en la cuenca propia del Júcar, si no se hubiera interpuesto el interés particular» ${ }^{30}$; y el propio Plan añadía que «...los problemas del Júcar están destinados a recibir su solución con los del Segura y el Almanzora, en el plan de conjunto o general de mejora y ampliación de los regadíos de Levante» ${ }^{31}$. Las otras propuestas, todas ellas de carácter preferente, para la cuenca del Júcar eran, además de los tres embalses citados y el de Forata, pendiente de estudio, los canales de Albacete, Alto Júcar, derivado éste del pantano de Tous, y de la orilla derecha, que arrancaba también de este reservorio, así como modificaciones y obras nuevas que resultaran de los estudios en curso.

Con anterioridad a la construcción de Alarcón, ninguno de los embalses en la red hidrográfica del Júcar llegaba a $15 \mathrm{hm}^{3}$; los mayores eran los de la Toba $\left(1925,11 \mathrm{hm}^{3}\right)$ y Embarcaderos $\left(1952,11 \mathrm{hm}^{3}\right)$, mientras los restantes, salvo El Molinar (1951, $\left.4 \mathrm{hm}^{3}\right)$, pertenecientes, en su mayoría (El Bujioso, 1912; Villova, 1914; La Lastra, 1927), al Cabriel o, incluso, radicado en alguno de sus tributarios (El Batanejo, 1921, río Guadazón), no alcanzaban el hectómetro cúbico. El único objetivo de esta serie de pequeños reservorios, el menor de los cuales es Picazo (1953, 0,05 hm³) sobre el propio Júcar, consiste en el aprovechamiento hidroeléctrico; excepto La Toba, cuya titularidad corresponde a UniónFenosa (Unión Eléctrica Madrileña, S.A., en el momento de su construcción), el resto, concesiones actuales de Iberdrola, fueron construidos por Hidroeléctrica Española, S.A., la gran empresa de esta naturaleza en el Júcar.

Hito decisivo para la regulación de la cabecera y cuenca superior del Júcar marcó la terminación, en 1957, del hiperembalse de Alarcón, con la finalidad conjunta de riego y producción de energía, a iniciativa de la Unión Sindical de Usuarios del Júcar (U.S.U.J), integrada por los regantes de la Acequia Real e «Hidroeléctrica Española, S.A.». Un gigantesco vaso de 6.480 hectáreas y $1.112 \mathrm{hm}^{3}$, que sumergió el pueblo de Gascas y parte de Valverde de Júcar, queda cerrado, $40 \mathrm{~km}$ aguas abajo, por un colosal dique emplazado al comienzo de las Hoces de Alarcón. Se trata de una presa de gravedad de $71 \mathrm{~m}$ de altura y una longitud en coronación de $317 \mathrm{~m}$, aprovechados por la carretera Madrid-Valencia; el aliviadero, de compuertas, posee una capacidad de $1.750 \mathrm{~m}^{3} / \mathrm{s}$, cifra relativamente modesta en relación con los 4.500 de la segunda presa de Tous, que responde no sólo a la capacidad

\footnotetext{
30 I Plan Nacional de Obras Hidráulicas, I, pág. 160.

31 I Plan Nacional de Obras Hidráulicas, I, pág. 158.
} 
muy superior de Alarcón sino a que las puntas de las crecidas de cabecera quedan muy por bajo de las que, generadas en tierras valencianas, ha registrado Tous. El hiperembalse de Alarcón ha modificado radicalmente el régimen del Júcar, acomodándolo a las necesidades de la demanda para los usos indicados; además, allí se produce la conjunción de las aguas del Júcar con las del acueducto Tajo-Segura, si bien éstas, aforadas, continúan hasta el contraembalse del Henchidero, para luego bifurcarse, el caudal del Júcar hacia la Central de El Picazo o Castillejos, mientras el trasvasado, acrecentado a veces por alguna transferencia del Júcar para la Mancomunidad de los Canales del Taibilla, continúa hacia una gran balsa de acumulación.

El uso del agua para la producción de energía eléctrica es antiguo e importante en el Júcar, particularmente en el macizo del Caroig, plataforma calcárea donde la erosión remontante, que ha producido la captura del Júcar manchego por el mediterráneo, y los procesos de disolución combinados han hecho posible que el río labre una larga y profunda garganta, en la que se escalonaban los embalses de Cortes I, Embarcaderos y Millares, englobados los dos primeros por el actual de Cortes II $\left(116 \mathrm{hm}^{3}\right)$ e invadido el último por la cola de la presa del Naranjero. Es de resaltar que, amén de dichas centrales, Iberdrola cuenta, en este tramo del río, con la central nuclear de Cofrentes, refrigerada por sus aguas, y el complejo de Cortes II-La Muela, ya mencionado, que permite, merced a una concesión de $40 \mathrm{hm}^{3}$, el almacenamiento del excedente de aquélla en horas-valle.

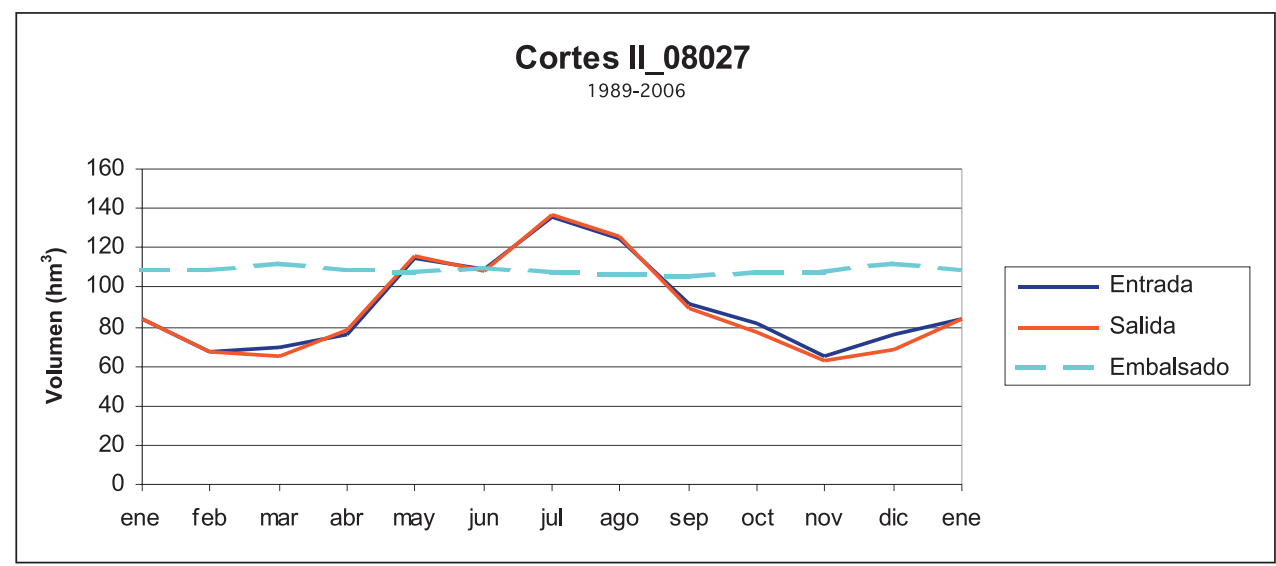

FIGURA 5. El profundo y largo congosto tajado por el Júcar en el macizo del Caroig ha permitido un temprano, intenso y diverso acondicionamiento hidroeléctrico, que incluye, además de la tradicional generación de energía, la refrigeración de la central nuclear de Cofrentes y el almacenamiento de sus excedente en horas-valle mediante el complejo de Cortes II-La Muela, que precisa la existencia en el primero de estos embalses de una reserva de $40 \mathrm{hm}^{3}$. Para resolver la competencia con el uso agrícola que originaba la turbinación de caudales en invierno, se construyó el contraembalse de El Naranjero, remodulación ésta que realiza ahora, entre otras funciones, la segunda presa de Tous (379 $\mathrm{hm}^{3}$ ). La práctica superposición de curvas, con sólo un ligero desfase de otoño-invierno, revela que Cortes II da salida por entrada, manteniendo la reserva precisa para el funcionamiento del complejo de La Muela.

En el embalse de Cortes II, a la altura de Cofrentes, afluye al Júcar su tributario más caudaloso, el Cabriel, también con notable aprovechamiento hidroeléctrico y controlado por el hiperembalse de Contreras $\left(884 \mathrm{hm}^{3}\right)$, con dos cerradas (Contreras y Collado) y un 
aliviadero de $2.475 \mathrm{~m}^{3} / \mathrm{s}$; parte de las aguas represadas se consumen en abastecimientos y riego. El respectivo control de las cabeceras de Júcar y Cabriel por Alarcón y Contreras no era suficiente, por cuanto los mayores aluviones, que secularmente han devastado la Ribera, se gestan aguas abajo de ambas presas, a partir del Caroig, tal y como evidenció la catastrófica avenida de 20-21 de octubre de 1982, que arruinó la presa de Tous, incapaz de laminar una avenida de tal entidad, y ocasionó una desastrosa anegación de La Ribera. Es de subrayar que la citada presa venía funcionando como un azud, y quizá ese limitado papel ayude a comprender su insuficiente mantenimiento.

Para solventar el serio problema del llano de inundación, se ha construido la segunda presa de Tous en la misma cerrada de la anterior y también de escollera, pero a diferencia, con vaso de $379 \mathrm{hm}^{3}$ y aliviadero de lámina libre para $4.500 \mathrm{~m}^{3} / \mathrm{s}$; este nuevo embalse, cuyo objetivo primordial es la defensa de avenidas, constituye asimismo dispositivo esencial de la regulación del Bajo Júcar, permite la remodulación de los caudales turbinados en las centrales del Caroig, garantiza el abastecimiento del área metropolitana de Valencia y el riego en La Ribera y Canal Júcar-Turia, con producción hidroeléctrica a pie de presa.

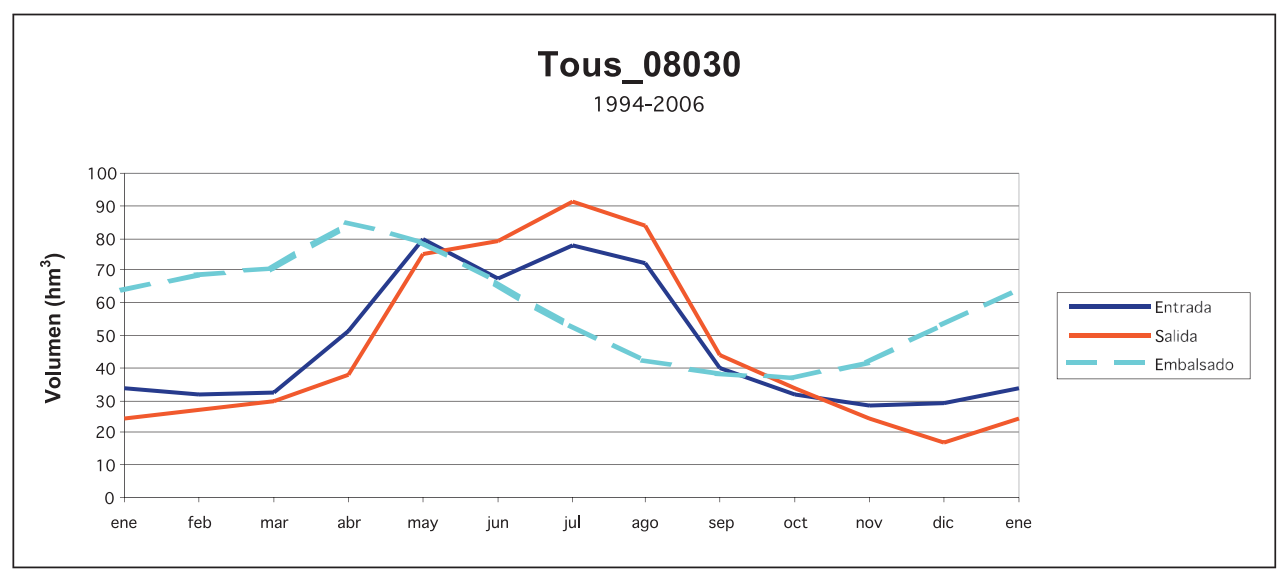

Figura 6. Arruinada la primera presa de Tous $\left(50 \mathrm{hm}^{3}\right)$, cuyo papel había sido el de azud, por la colosal riada de 20 de octubre de 1982, se ha levantado la de Tous II, con vaso casi ocho veces superior. Cometido esencial de este hiperembalse es la laminación de las ondas de crecida que, originadas en el Caroig, han devastado históricamente La Ribera; otros adicionales son los de remodular el caudal del Júcar y mejorar su regulación, como garantía de las demandas agrícolas y urbana, ya que aquél suplementa al Turia en el abastecimiento del área metropolitana de Valencia.

La riada de 20-21 de octubre de 1982 hizo patente la urgente necesidad de regular los afluentes mediterráneos, cuya contribución al cataclismo de La Ribera no había sido desdeñable. A los pantanos de Forata $\left(1969,39 \mathrm{hm}^{3}\right)$, en el Magro, sobre el que se halla prevista la presa del Marquesado, y de Bellús $\left(69,2 \mathrm{hm}^{3}\right)$, que recibe las aguas del Cañoles, Clariano, Albaida y Micena, ha venido a sumarse el de Escalona, en este curso, con capacidad de $92 \mathrm{hm}^{3}$ y aliviadero de $7.913 \mathrm{~m}^{3} / \mathrm{s}$, y están proyectadas las presas de Montesa en el Cañoles y la del Sellent. 


\section{Repercusiones de la evolución de cultivos en el régimen del Júcar}

La gran ampliación de la superficie atendida por los tramos antiguo y nuevo de la Acequia Real, con presencia mayoritaria del arrozal, se dejó sentir en el régimen del Júcar, aguas abajo de Antella, por una sensible mengua del módulo, sobre todo en la Ribera Alta, y el agravamiento de los estiajes veraniegos y de la reducción de caudales en los períodos de sequía. Con todo, la importancia del arrozal tenía asimismo otras consecuencias, con incremento de retornos e incidencia de signo opuesto en las inundaciones tardoestivales. El riego copioso por inundación de las balsas de arroz ocasionó un elevado volumen de aguas de retorno, durante los meses de primavera y verano en la Ribera Baja, al propio Júcar por el Río Verde y los ullals, a los marenys o aguazales costeros, con la Albufera a la cabeza, y a acequias, muy abundantes y desbordantes en esa época, que vierten directamente al Mediterráneo por Sueca y Cullera.

El arroz, segado a finales de verano, favorecía la evacuación en el llano de inundación de las aguas desmadradas del Júcar con ocasión de sus grandes avenidas tardoestivales, si bien en algunas de ellas, particularmente en la de 4-5 de noviembre de 1864, la peor de que hay noticia histórica, su paja, arrastrada por aquéllas, se convirtió en terrible instrumento, tal y como subrayó la Memoria sobre la inundación elaborada bajo la dirección de Bosch y Juliá, en los términos siguientes: «La paja de arroz no destruyó los puentes, las presas y los edificios, pero á la sorda causó en la Ribera más daños que las maderas. Sería curioso conocer el número exacto de moreras, naranjos y otros árboles derribados por la paja de arroz. Por esta razón hemos insistido tanto sobre este punto. El fenómeno no ha sido casual. La paja de arroz ha causado grandes perjuicios en otras crecidas anteriores a la de 1864, y los producirá en lo sucesivo si no se toman serias medidas.

El arroz temprano está en disposición de segarse por la Virgen de Agosto. La siega de arroz suele terminar en la Ribera a primeros de Setiembre. Hay la mala costumbre de dejar diseminadas por el campo o amontonadas formando hacinas (garberas) las partes de las garbillas de que se han separado las espigas, cuyo valor es insignificante. El 90 por 100 de esta paja se quema en el campo, sirviendo las cenizas de abono. El 10 por 100 restante sirve de combustible para los hormigueros; se la utiliza para cama de los ganados, para techos de las barracas, para atochadas, para abrigos en la agricultura y otros usos de ménos importancia. Del 15 de Setiembre en adelante, la mayor parte de los años está bastante seca para ser quemada. Cuando al labrador le interesa dejar desahogadas las tierras que se han de sembrar de habas, se da prisa en quemar la paja de arroz: entonces durante el mes de Setiembre desaparece. Cuando nada le apresura, retarda la operación. La paja queda abandonada por más o menos tiempo; vienen las crecidas del Júcar, y ocasionan las males que hemos descrito en la reseña agrícola. Si se quemase la paja en tiempo oportuno, ó sea antes del 15 de Octubre, se destruiría uno de los elementos que más daños causan en las inundaciones, $\tan$ frecuentes durante el mes de Noviembre. No sólo debiera quemarse la paja de arroz, sino las cañas de maiz (cañots), que forman gran parte de la remugá, como llaman algunos labradores de la Ribera, que bajan las aguas en las fuertes avenidas. Ninguna dificultad puede oponerse á esta medida, cuya importancia no desconocerá nadie que haya presenciado el triste cuadro que presentaba la Ribera en Diciembre de 1864».

Los renglones de la Memoria transcritos mencionan, por su especial involucración en la inundación, cuatro cultivos, de por mitad arbóreos (morera, naranjo) y herbáceos (arroz, maíz), arrancados o dañados los primeros por las bardomeras (remugás) de paja y matas de los segundas que arrastraron furiosamente las aguas desmadradas. El arroz era, por entonces, el cultivo al que mayor superficie se dedicaba en La Ribera y el maíz también superaba en extensión al trigo; en consecuencia, dos cereales de verano, que demandaban riego en 
período seco y de aguas bajas, profundizando los estiajes. Por otra parte, el catastrófico aluvión de 1864 aceleraría el retroceso de la morera, ya que gran parte de las arracadas o arruinadas entonces no serían repuestas en una situación muy negativa y desfavorable para la seda valenciana, al coincidir la obsolescencia de la industria, fuerte competencia oriental y la epizootia de la pebrina.

Existe hoy en la Ribera del Júcar un fuerte y creciente desfase entre concesiones históricas de aguas afluyentes y consumos agrícolas. En efecto, éstos han experimentado una acusada disminución durante el último cuarto de siglo, primordialmente a consecuencia de la sustitución del cultivo de arroz por el de cítricos y del amplio retroceso de la superficie de regadío. Como se ha indicado, a comienzos del siglo XX más de la mitad de las tierras regadas por la Acequia Real del Júcar eran de arrozal, mientras en la actualidad, salvo un reducido espacio en la marjal d'Algemesí, el arroz ha desaparecido de la Ribera Alta y retrocedido asimismo en la Baja a favor de naranjos y mandarinos. Y es de recordar que mientras la hectárea de arrozal precisa, por término medio, en la Ribera del Júcar 15.000 $\mathrm{m}^{3} / \mathrm{año}$, los cítricos tienen suficiente con la mitad de ese volumen. Por otra parte, los regadíos tradicionales de La Ribera han perdido en torno a una tercera parte de la extensión que poseían hacia 1975 a causa de polígonos industriales y la construcción de grandes infraestructuras de comunicación, tales como la autopista A-7, sus accesos y enlaces, desvíos urbanos, ampliación de antiguas carreteras comarcales y acceso a Levante del tren de alta velocidad. Todo ello ha contribuido a reducir el volumen total de consumo agrícola de agua en La Ribera.

Es de resaltar que los regadíos tradicionales de La Ribera se encuentran ante el dilema de modernizarse o desaparecer, por razones de rentabilidad. Con independencia de que se envíe o no agua para atenuar el fortísimo déficit hídrico del Vinalopó-L'Alacantí-Marina Baja, lo cierto es que la modernización, con la obligada incorporación del riego por goteo, resulta necesaria e inaplazable, no por disminuir el consumo de agua sino por ajustar unos costes insoportables, con los cuales la citricultura de la Ribera, en este aspecto, ha perdido competitividad tanto en el mercado nacional como en los internacionales. Esa imprescindible sustitución del riego de inundación o a manta actual, ampliamente hegemónico en La Ribera del Júcar, por el riesgo localizado de goteo, reducirá poderosamente la presencia de aguas de retorno en la Ribera Baja, es decir, tanto en el Azud de la Marquesa como en las golas del Mareny de Barraquetes y del Mareny de San Lorenzo. Consecuencia previsible de todo ello es que, al tiempo que se incrementan los caudales disponibles, por las razones apuntadas, en Cortes, caerán drásticamente en el área de la desembocadura del Júcar y espacios aledaños.

Por otra parte, la sustitución del arrozal por los cítricos y la implantación de grandes infraestructuras de comunicación en dirección más o menos meridiana ha alterado las condiciones de circulación de las aguas desmadradas en el llano de inundación de La Ribera, tal y como se evidenció con motivo de la gran avenida fluvial, con rotura de la presa de Tous incluida, de 20-21 de octubre de 1982, cuando la trinchera del ferrocarril y, sobre todo, la autopista A-7 represaron la crecida, dificultando la evacuación e incrementando los calados; consecuencia ésta favorecida por el incremento de los coeficientes de rugosidad que resulta del reemplazo de las balsas de arroz, en esa época cosechadas y libres, por plantaciones de naranjos y mandarinos, esencialmente en la Ribera Alta.

En suma, el régimen pluvionival de raigambre atlántico-mediterránea subtropical, fruto de una encrucijada climática que proporciona caudal de base de procedencia atlántica, temibles aluviones otoñales de filiación mediterránea y aguas bajas estivales y sequías de carácter subtropical, ha sido intensamente desnaturalizado por la intervención humana, sobre todo en la segunda mitad del siglo XX con la regulación de las subcuencas superiores 


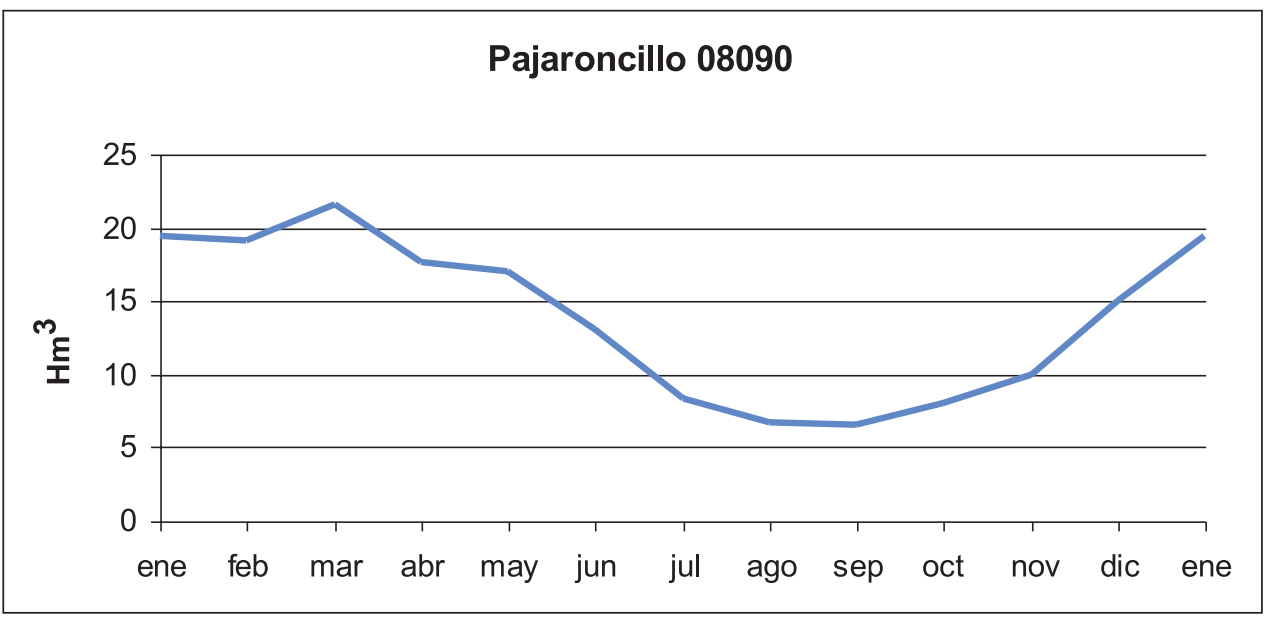

FIGURA 7. El aforo de Pajaroncillo muestra el régimen natural del alto Cabriel, pluvionival de raigambre atlántica-mediterránea subtropical. Allí radicaba el aguadero de Cristinas, por el que durante siglos se flotaron las maderadas de laricio que, procedentes de la Serranía de Cuenca, descendían por el río hasta Cofrentes, donde pasaban al Júcar y proseguían viaje, generalmente, a Alcira.

de Júcar y Cabriel por los hiperembalses respectivos de Alarcón y Contreras, extracción masiva de recursos subterráneos del acuífero de la Mancha Oriental, acondicionamiento hidroeléctrico del Caroig con el embalse de Cortes II y el complejo de Cortes-La Muela y defensa de avenidas mediante el dispositivo estructural de las presas, levantadas a raíz de las inundaciones de octubre de 1982 y noviembre de 1987, de Tous II, Escalona y Bellús. El ritmo circulatorio y la curva de coeficientes anual originarios, que presentan pico pri-

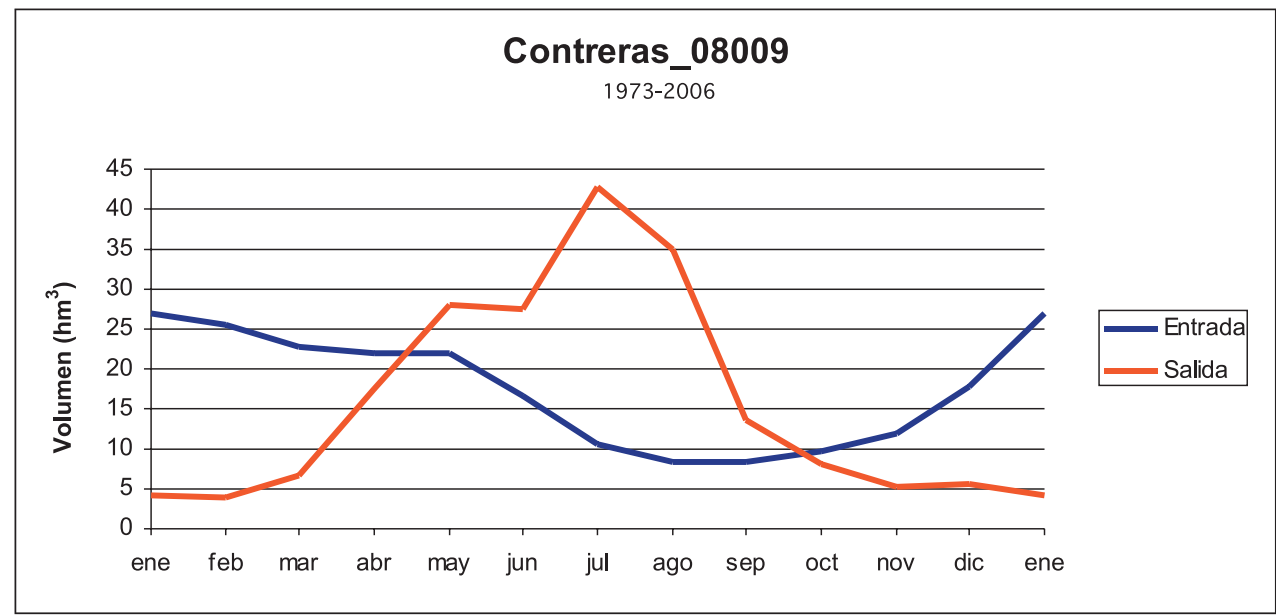

FIGURA 8. El hiperembalse de Contreras ha modificado radicalmente el régimen natural del Cabriel, acompasándolo a las demandas agrícola, urbana e hidroeléctrica, de manera que la curva de módulos mensuales ha quedado invertida, ya que las salidas proporcionan aguas altas de verano y bajas en invierno. 
maveral pluvionival, mínimos principal de estío y secundario de enero, éste por descenso de precipitaciones y retención nival, con repunte de origen tormentoso en junio, han sido modificados, al extremo de resultar invertidos, por los desembalses; acompasados éstos a la demanda, supeditada al uso agrícola, el período de aguas altas ha pasado a primavera avanzada y verano, con pico de julio, mientras las aguas bajas se trasladan a otoño-invierno, con mínimo en octubre. Anotemos, no obstante, una cierta suavización de la fortísima polarización estival de la demanda agrícola, por el acusado retroceso del arrozal en La Ribera durante el último cuarto de siglo XX. Hagamos notar también el perjuicio que para la regularidad natural del Júcar y su memoria histórica representa los ingentes bombeos del acuífero de la Mancha Oriental.

Y, por último, en cuanto a sequías e inundaciones, las diversas medidas y precauciones resultan más eficaces para las segundas, tal y como se puso de manifiesto el 30 de septiembre de 1997, que en las primeras, la última de las cuales, que duró de 1992 a 1995 , se dejó sentir de manera intensa en los veranos de 1994 y 1995. En resumidas cuentas, la profunda alteración del régimen natural ha conseguido reducir, pero en modo alguno descartar de la cuenca valenciana del Júcar los riesgos extremos de grandes avenidas y graves sequías. Casi mediado el siglo XIX, el Diccionario de Madoz sintetiza las derivaciones del Júcar aguas abajo de Tous en los términos siguientes: «El curso del río por la provincia de Valencia es perenne y bastante caudaloso: hasta Tous se calculan sus aguas en 1.299 filas; la que le dan sus afluentes hasta su desagüe, es de 669, de modo que si no se le sangrase en todo su curso, llevaría al mar una columna de agua de 1.968 filas. Estas se distribuyen de la manera siguiente: antes de llegar al río Sellent toman, la acequia de Escalona 50, la de Antella 12, la de Carcagente 66 112. De estas sólo se toman 466 por medio de 4 acequias que son, la de Riola 77 1/2, la de Sueca 163 1/2, la de Fortaleny 63, y la de Cullera 162, desembocando en el mar sobre 755 1/2.

Aun cuando La Ribera no cuenta con una red de avenamiento de aguas muertas como las Vegas Media y Baja del Segura, los retornos del riego por inundación o a manta han sido

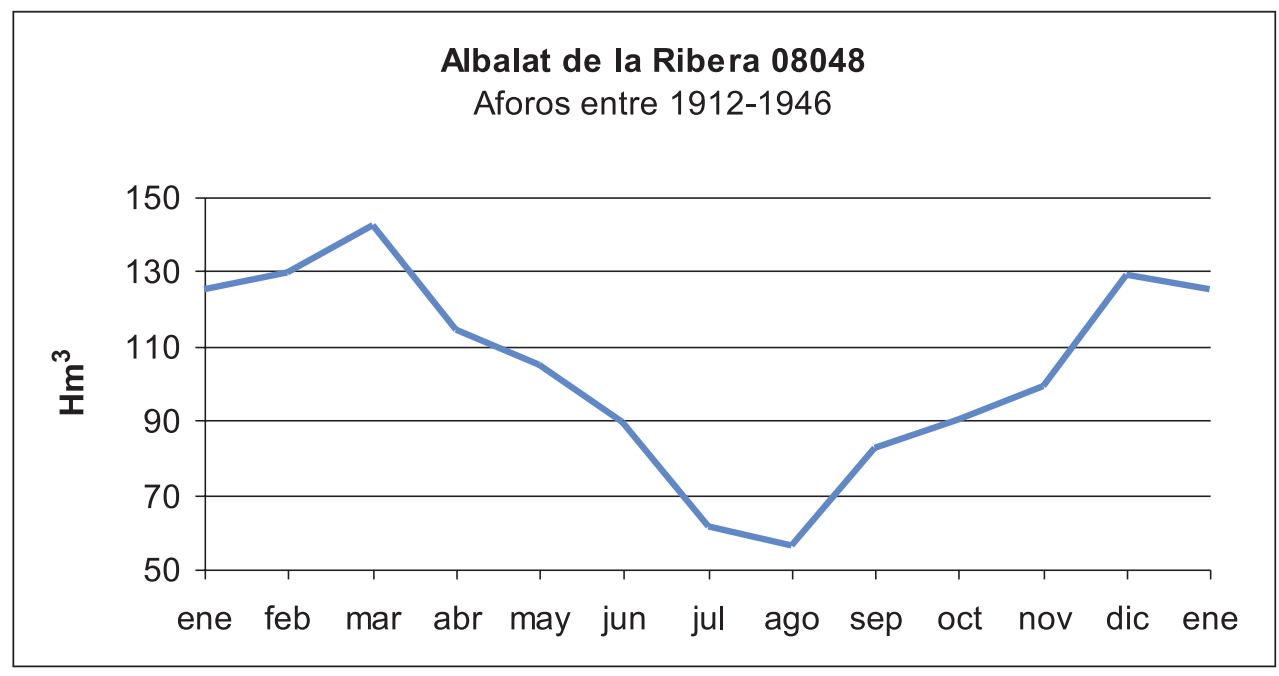

Figura 9. En el periodo considerado, el aforo del Albalat proporciona, prácticamente, la curva de aguas fluyentes, si bien con el mínimo estival agravado y profundizado por la detracción esencial, con otras menores, de la Acequia Real del Júcar. 


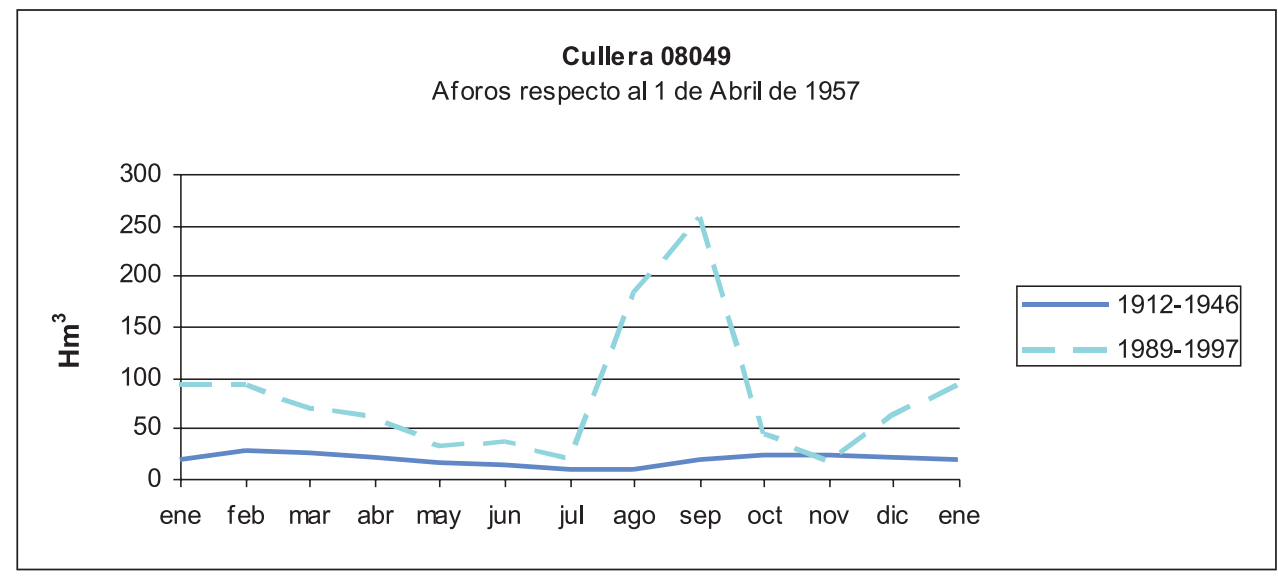

Figura 10. En desembocadura, la antigua curva aplanada del Júcar, con mínimo de agosto, ha sido reemplazada, tras su regulación, por otra donde sobresale una rotunda elevación en dicho mes y septiembre a causa de los retornos procedentes de los arrozales, antes menores y consumidos aguas arriba del aforo.

históricamente, y todavía lo son, muy cuantiosos. Merced a ellos, un Júcar disminuido, por las sucesivas tomas de las acequias en la Ribera Baja experimenta una notable recuperación de su módulo, bien patente, al inicio de la Ribera Baja, en el aforo de Albalat (39 $\left.\mathrm{m}^{3} / \mathrm{s}\right)$. A ese restablecimiento contribuyen, además de su tributarios naturales, el río de los Ojos o Verde y multitud de afloramientos (ullals, brolladors) alimentados por las aguas de riego. El citado Diccionario de Madoz describe el río de los Ojos del modo siguiente: «... en su mismo nacimiento comienzo la acequia de Alfait de un muela de agua, que dirigiéndose hacia el Norte riega parte del término de Masalaves, y describiendo una curva vuelve al mismo río (Júcar) cerca del término de Alcira. No fertiliza otras tierras con sus aguas hasta su desagüe en el río Júcar, por el Norte de Alcira después de 1 leg. de curso, no por otra razón sino porque su cauce es muy profundo, si bien da movimiento á 3 molinos... Aunque en su nacimiento no lleva más que 3 muelas de agua, como en su curso recibe los sobrantes de todos los campos de Alberique, Masalaves, Montortal, Benimuslem, Puchol, Guadasuar y Alcira, llega á hacerse caudaloso en términos que cuando se despide del part. Jud. de Alberique para entrar en el de Alcira, lleva por término medio más de 10 muelas de agua». Cien años después, la extracción y elevación de caudales en el área de cabecera del río Verde, por la Sociedad Regadíos Valencianos (Reva) permitió la ampliación del regadío en los municipios de Carlet y Alcudia de Carlet.

Finalmente, un cambio importante y previsible en la situación originada por la fuerte expansión del arrozal en los doscientos años que van desde 1754 a mediados del siglo $\mathrm{XX}$, causante de abundantes retornos al Júcar y a los marenys o aguazales costeros de la Ribera Baja, puede suponer la difusión del riego por goteo, imprescindible para aminorar los gravosos e insoportables costes de producción en los huertos, al ocasionar la drástica disminución de los citados reintegros y, en consecuencia, reducir la recuperación que experimenta, merced a aquéllos, desde Albalat, el módulo del Júcar. 


\section{Bibliografía}

ARMENGOT, R. (1994): «Les precipitacions extraordinàries», en PÉREZ CUEVA, A. (coord).: Atlas climàtic de la Comunitat Valenciana,(1961-1990), Generalitat Valenciana, Colecció Territori, nº4, págs. 98-99.

ARENILLAS, M. et al. (1985): «La avenida estraordinaria del Xúquer de 20 de octubre de 1982», en Catástrofes naturales, Valencia, Publicaciones de la Cátedra de Geología Aplicada a las Obras Públicas de la Universidad Politécnica de Valencia, págs. 17-49.

BALLESTER BROCETA, B. (1877): Acequia Real del Júcar. Reflexiones sobre la escasez de aguas en dicho canal y rápida ojeada sobre el Júcar..., València, Impremta J. Doménech.

BOIX, V. (1865): Memoria histórica de la inundación de la Ribera de Valencia en los días 4 y 5 de noviembre de 1864, Valencia, La Opinión, 260 págs.

BOSCH Y JULIÁ, M. (1866): Memoria sobre la inundación del Júcar en 1864, presentada al Ministerio de Fomento por D...., Madrid, Imprenta Nacional, 398 págs.

BOTELLA, A. y SALOM, J. (1983): «Las inundaciones del Xúquer en 1982. Repercusiones en el sector industrial», Cuadernos de Geografía, no 32-33, págs. 187-212.

BUTZER, K.W. et al. (1983): «Las crecidas medievales del río Júcar según el registro geoarqueológico de Alzira», Cuadernos de Geografía, no 32-33, págs. 311-332.

BUTZER, K.W., MIRALLES, I., MATEU, J.F. (1983): «Las crecidas medievales del río Júcar según el registro geo-arqueológico de Alzira», Cuadernos de Geografía, 32-33, págs. 311-331.

CALATAYUD GINER, S. (1984): «Transformaciones jurídicas y sociales en la Acequia Real del Júcar durante el siglo XIX», Estudis d'Història Contemporània del País Valencià, Valencia, págs. 295-321.

CALATAYUD GINER, S. (1993): «Límits i transformacions del sistema de reg a la Ribera del Xúquer durante el segle XIX», Actes de la V Assemblea d'Història de la Ribera, l'Alcudia, Ajuntament, págs. 315-328.

CALATAYUD GINER, S. (2000): «Els sistemes de reg a les riberes del Xúquer durant l'època contemporània (1800-1930): continuïtat i canvi», L'espai de l'aigua. Xarxes i sistemes d'irrigació a la Ribera del Xúquer en la perspectiva històrica, Ajuntament d'Alzira i Universitat de València, Valéncia, págs. 275-306.

CALVO, A. y FUMANAL, Mª P. (1983): «Repercusiones geomorfológicas de las lluvias torrenciales de octubre de 1982 en la cuenca media del Júcar», Cuadernos de Geografía, no 32-33, págs. 101-120.

CANO GARCÍA, G.M. (1980): «La Ribera del Júcar, una transformación reciente», Los paisajes rurales de España, Valladolid, Asociación de Geógrafos Españoles, págs. 267-275.

CARMONA, P. y SEGURA, F. (1989): «Estudio sedimentológico de los depósitos de inundación en la Ribera del Xúquer (Valencia), en Octubre de 1982», Cuaderno de Investigación Geográfica, Tomo XI, págs. 65-74.

CARMONA, P. y SEGURA, F. (1989): «La inundación del Xúquer en noviembre de 1987», Сuadernos de Geografía, 46, págs. 97-106, Valencia.

CARMONA GONZÁLEZ, P. y RUIZ PÉREZ, J.M. (2000): Las inundaciones de los ríos Júcar y Turia, Serie Geográfica, Universitat de València, 9, págs. 49-69.

CASTELL LLÁCER, V. (1971): El paisaje agrario de Algemesí, Valencia, Institución Alfonso el Magnánimo, 136 págs.

CAVANILLES, A.J. (1795-97): Observaciones sobre la Historia Natural, Geografía, Agricultura, Población y Frutos del reino de Valencia, Madrid, Imp. Real, 2 vols., edición facsímil, Valencia, Albatros, 1972, 2 vols.

COLLADO AUCEJO, F. (1990): Estudio de evaluación de las características de los aprovechamientos de aguas de las comunidades de regantes del Valle de Cárcer y Sellent, riesgos de Estubeny y Acequia de Escalona, M.O.P.U., Dirección General de Obras Hidráulicas y Confederación Hidrogràfica del Júcar, F.P.800.006.

COPUT (1997): Delimitación del riesgo de inundación a escala regional en la Comunidad Valenciana. Generalitat Valenciana, Consellería d'Obres Públiques, Urbanisme i Transports, Serie Cartográfica Temática, 1, 56 pág. más cartografía. 
CONFEDERACIÓN HIDROGRÁFICA DEL JÚCAR (1985): Plan General de defensa contra las Avenidas en la Cuenca del río Júcar.

CONFEDERACIÓN HIDROGRÁFICA DEL JÚCAR (1998): Proyecto del Plan de Actuaciones para la Reducción de los Riesgos de Inundación en el Tramo del río Júcar entre la incorporación del río Albaida y Polinyà de Xúquer y Barrancos Adyacentes (Valencia), INTECSA.

CONFEDERACIÓN HIDROGRÁFICA DEL JÚCAR (1999): Estrategias de actuación en la zona inundable de la Ribera del Júcar. Volumen I, Proceso de participación, Alzira, 29-30 de marzo de 1999.

CONFEDERACIÓN HIDROGRÁFICA DEL JÚCAR (1999): Plan global frente a inundaciones en la Ribera del Júcar: líneas de actuación.

FAUS PRIETO, A. (2000): «Trabajos de hidrometría y cartografía en la Ribera del Xúquer y su acequia Real (siglos XVI-XVIII)», L'espai de l'aigua. Xarxes i sistemes d'irrigació a la Ribera del Xúquer en la perspectiva històrica, Ajuntament d'Alzira i Universitat de València, València, págs. 221-244.

FERRER, V. (1985): «El contacte entre la Ribera del Xúquer y els raiguers de les muntanyes de Carcaixent», Cuadernos de Geografía, 36, págs. 1-20.

FOGUÉS, F. (1931): «Las inundaciones de la Ribera», Anales del Centro de Cultura Valenciana, IV-10, págs. 232-250.

FURIÓ, A. y CALATAYUD GINER, S. (1992): «El sistema de riegos en Sueca y la construcción de la Comunidad de Regantes», en Historia y constitución de las comunidades de regantes de las Riberas del Júcar (Valencia), Valencia, Ministerio de Agricultura, Pesca y Alimentación, págs. 297-340.

FURIÓ, A. y LAIRÓN, A. (2000): L'espai de l'aigua. Xarxes i sistemes d'irrigació a la Ribera del Xúquer en la perspectiva històrica, València, Universitat de València i Ajuntament d'Alzira (Eds.).

FURIÓ, A. y MARTÍNEZ, L.P. (1994): «Assunts i molins sobre el Xúquer en la Baixa Edat Mitjana», Actes IV Congrés d'Arqueologia Medieval Espanyola ( «Societats en transició»), Alacant, Generalitat Valenciana, Associació Espanyola d'Arqueologia Medieval i Ajuntament d'Alacant, págs. 575-586.

GARCÍA FERNÁNDEZ, J. (1971): «El cultivo del arroz y su expansión en el siglo XVIII en los llanos meridionales del golfo de Valencia», Estudios Geográficos, nº 123, págs. 163-187.

GIMENO GÓMEZ, JOSÉ (1983): El pantano de Tous. La riada trágica, su historia. Grafiques Gimeval, l'Alcudia, 221 págs.

GINER I PEREPERES, F. (1992): «Los riegos del Júcar en la época foral hasta el año 1690», Historia y constitución de las comunidades de regantes de las Riberas del Júcar (Valencia), Valencia, Ministerio de Agricultura, Pesca y Alimentación, págs. 345-368.

GÓMEZ ORTEGA, J.F., LIZARRAGA, J.F., DE CHURRUCA, E. (1865): Estudio de las inundaciones del Júcar de 1864. Facsímil editado por la Confederación Hidrográfica del Júcar en 1988, 282 págs.

GUAL CAMARENA, M. (1979): Estudio histórico-geográfico sobre la Acequia Real del Júcar, València, Alfons el Magnànim.

JAUBERT DE PASSA, F.J. (1844): Canales de riego de Cataluna y Reino de Valencia, leyes y costumbres que los rigen, reglamentos y ordenanzas de sus principales acequias, Valencia, Imprenta Benito Monfort.

LA ROCA, N. y CARMONA, P. (1983): «Fotointerpretación de la Ribera del Xúquer después de la inundación de octubre de 1982», Cuadernos de Geografía, 32-33, págs. 121-136.

MADOZ, P. (1846-50): Diccionario Geográfico-Estadístico-Histórico de España y sus posesiones de Ultramar, 16 vols.

MARCO, J. (1999): «Análisis Hidrológico y sus implicaciones en la planificación de una defensa integral frente a las inundaciones de la Ribera del Júcar», en CONFEDERACIÓN HIDROGRÁFICA DEL JÚCAR, Estrategias de actuación en la zona inundable de la Ribera del Júcar, Volumen I, Ponencias Técnicas, Alzira, 29-30 marzo de 1999.

MARCO SEGURA, J. (2004): «Evolución histórica del sistema de aprovechamiento y su impacto sobre el régimen hídrico de los ríos Júcar y Turia», Alteración de los regímenes fluviales peninsulares, Fundación Cajamurcia e Instituto Euromediterráneo de Hidrotecnia, págs. 329-348. 
MARTÍN VIDE, J. (1994): «Precipitacions: màxims diaris, probables e irregularitat», Atlas climàtic de la Comunitat Valenciana (1961-1990), Generalitat Valenciana, págs. 94-96.

MARTÍNEZ FERREROS, Y. (1992): «La meandrización en el llano de inundación del Xúquer», Cuadernos de Geografía, 51, págs. 23-41.

MASACHS ALAVEDRA, V. (1948): El régimen de los ríos peninsulares, Barcelona, CSIC, 511 págs.

MATARREDONA, R., PÉREZ CUEVA, A. y SANCHIS, E. (1989): «Los ríos valencianos y su régimen», Guía de la Naturaleza de la Comunidad Valenciana, Institució Alfons el Magnànim, págs. 491-520.

MATEU BELLÉS, J. (1980): «El llano de inundación del Xúquer (País Valenciano): geometría y repercusiones morfológicas y paisajísticas», Cuadernos de Geografía, n 27, págs. 121-142.

MATEU BELLÉS, J. (1983): «Aluvionamiento medieval y moderno en el llano de inundación del Júcar», Cuadernos de Geografía, no 32-33, págs. 291-310.

MATEU BELLÉS, J. (1983): «La ciència i la tècnica davant les revingudes del Xúquer (1635-1905). Notes preliminars», Cuadernos de Geografía, no 32-33, págs. 243-264.

MATEU BELLÉS, J.(1983): «La riada del Júcar y sus efectos en la Ribera», Estudios Geográficos., no 170-171, págs. 187-222.

MATEU BELLES, J. (1983): La inundación en la Ribera del Xúquer (20-21 de octubre de 1982), Estudios Geográficos, 170-171, págs. 187-221.

MATEU BELLÉS, J. (1988): «Crecidas e inundaciones en el País Valenciano», Guía de la Naturaleza de la Comunidad Valenciana, Institució Alfons el Magnànim, págs. 565-608.

MATEU BELLÉS, J. (1992): «Cambios seculares de la agradación aluvial y de la meandrización en la Ribera Alta del Xúquer», Saitabi, XLII, págs. 183-205.

MATEU BELLÉS, J. (1999): «Análisis geomorfológico de la Ribera», en CONFEDERACIÓN HIDROGRÁFICA DEL JÚCAR, Estrategias de actuación en la zona inundable de la Ribera del Júcar. Volumen I, Ponencias Técnicas, Alzira, 20-30 de marzo de 1999.

MATEU TORTOSA, E. (1987): Arroz y paludismo. Riqueza y conflictos en la sociedad valenciana del siglo XVIII, Valencia, IVEI Alfons el Magnànim.

MATEU, J.F. y CARMONA, P. (1991): «Riesgos de inundación en las riberas del Túria y Júcar», Sociedad y Territorio, XII Congreso Nacional de Geografía, págs. 237-256.

MATEU TORTOSA, E. y CALATAYUD GINER, S.: «Control del agua y conflictividad social en la expansión del regadío: la Acequia Real del Júcar, 1840-1990», Areas, XVII, págs. 61-76.

MATOSES I CUQUERELLA, R.: «Bases del modern sistema de reg a Sueca: les provatures i les realitzacions del segle XVIII», Quaderns de Sueca, IX, 1987, págs. 25-38.

MIRANDA, M ${ }^{\text {a }}$ J. (1983): «Consecuencias en el sector agrícola de las inundaciones sufridas por la cuenca del Xúquer en octubre y noviembre de 1982», Cuadernos de Geografía, no 32-33, págs. 167-186.

PÉREZ CUEVA, A. y ARMENGOT, R. (1983): «El temporal de octubre de 1982 en el marco de las lluvias torrenciales en la cuenca baja del Júcar», Cuadernos de Geografía, 32-33, págs. 61-86.

PÉREZ CUEVA, A. (coord..) (1994): Atlas climàtic de la Comunitat Valenciana (1961-1990), Valencia, Conselleria d'Obres Publiques, Urbanisme i Transport, 205 págs.

PÉREZ MEDINA, T.V.: «Aproximació al paissatge agrari de Carcaixent en l'últim terç del segle XVI», Anàlisi local i Història comarcal: la Ribera del Xúquer (ss. XIV-XX). Actes de les II i III Assemblea d'Història de la Ribera, Valencia, Diputación de Valencia, págs. 85-102.

PÉREZ PUCHAL, P. (1967): «Los embalses y el régimen de los ríos valencianos», Estudios Geográficos, no 107 , págs. 149-196.

PERIS ALBENTOSA, Tomás (1991): «La problemática génesis del segundo tramo de la Acequia Real del Xúquer (orígenes de la «Acequia del Proyecto» del duque de Híjar (1728-1778)», Investigaciones Geográficas, 9, págs. 167-190.

PERIS ALBENTOSA, T (1992): «Conflictividad y administración de justicia en la Acequia Real de Alzira», Actes del I Congrés de la Administració Valenciana, Valencia, Generalidad Valenciana, Instituto Valenciano de Administración Pública, págs. 725-742.

PERIS ALBENTOSA, Tomás (1992): Regadío, producción y poder en la ribera del Xúquer (la Acequia Real de Alzira, 1258-1847), Valencia. 
PERIS ALBENTOSA, T. (1992): Regadío, producción y poder en la Ribera del Xúquer (la Acequia Real de Alzira, 1258-1847), València, COPUT i Confederación Hidrográfica del Júcar.

PERIS ALBENTOSA, T. (1992): «Toponomia y tecnología hidráulica en la Acequia Real de Alzira o del Xúquer», Al-gezira, VII, págs. 113-211.

PERIS ALBENTOSA, T.: (1992)»Gobierno y administración de la Acequia Real del Xúquer (siglos XV a XIX)», Historia y constitución de las comunidades de regantes de las Riberas del Júcar (Valencia), Valencia, Ministerio de Agricultura, Pesca y Alimentación, págs. 159-264.

PERIS ALBENTOSA, T.(1995): La séquia Reial del Xúquer (1258-1847), síntesi històrica i aportacions documentals, Alzira, Germania.

PERIS ALBENTOSA, Tomás (1997): «La conflictividad hidráulica en el País Valenciano entre los siglos XIII y XVIII», Áreas. Revista de Ciencias Sociales, 17, 43-60.

PERIS ALBENTOSA, T.(2000): «Aigua i molins en un macrosistema fluvial valencià. La molineria a la Ribera del Xúquer, segles XIII-XIX», Els molins hidràulics valencians. Tecnologia, història i context social (Glick, T., Guinot, E. y Martínez, L.P., eds.), Valencia, Alfons el Magnànim, págs. 273-357.

PERIS ALBENTOSA, Tomás (2000): «La Sèquia d'Èscalona: génesi i organització (1593-1783)», L'espai de l'aigua. Xarxes i sistemes d'irrigatió a la ribera del Xúquer en la perspectiva histórica, València, Universitat de València i Ajuntament d'Alzira, págs. 163-188.

PERIS ALBENTOSA, T. (2001): «L'escenari i els protagonistes», Història de La Ribera, vol. I, Alzira, Bromera, 250 págs.

PERIS ALBENTOSA, T. (2001-2002): Història de la Ribera. De vespres de les Germanies fins a la crisi de l'Antic Règim. Vol.I, L'escenari i els protagonistes, Alzira, Bromera, 2001; vol. III, Les jerarquies social, Alzira, Bromera, 2002.

PERIS ALBENTOSA, T. (2003): La gestió hidràulica en la Sèquia d'Escalona (1605-1993), 256 págs.

PERIS ALBENTOSA, T. y ROMERO GONZÁLEZ, J. (2000): «El regadiu de la Ribera del Xúquer, segles XV-XIX», L'espai de l'aigua: xarxes i sistemes d'irrigatió a la ribera del Xúquer en la perspectiva histórica, València, Universitat de València i Ajuntament d'Alzira, págs. 107-140.

PERIS ALBENTOSA, T., GUINOT, E., SELMA, S., MARTÍ, J. y VERCHER, S. (2001): La acequia Real del Júcar. Camins d'Aigua. El patrimonio Hidràulico Valenciano, Valencia, Conselleria de Agricultura, Pesca y Alimentación.

PERIS ALBENTOSA, T., ROMERO GONZÁLEZ, J. y PELLICER, R. (1994): «Regadío y estructuras de poder en el Mediterráneo español. La Acequia Real del Xúquer», Regadíos y estructuras de poder, GIL ALBERT, I.C., Alicante, págs. 151-192.

QUEREDA, J. (1983): «Los excepcionales temporales de octubre y su relación con las temperaturas del mar», Cuadernos de Geografía, 32-33, págs. 87-100.

ROSSELLÓ I VERGER, V.Ma . (1972): «Los ríos Júcar y Turia en la génesis de la albufera de Valencia», Cuadernos de Geografía, no 11, págs. 7-25, Valencia.

ROSSELLÓ I VERGER, V.Ma . (1979): «Anotaciones a la toponimia de la Ribera del Xúquer i encontorns», Cuadernos de Geografía, n 24, págs. 1-26.

ROSSELLÓ I VERGER, V.Mª . (1983): «La revinguda del Xúquer i el desastre de la Ribera (20-21 de octubre de 1982). Una perspectiva geográfica», Cuadernos de Geografía, no 32-33, págs. 3-38.

ROSSELLÓ I VERGER, V.Ma . (1983): «La formación de la riada del Júcar de 1982, aguas arriba de Tous», Estudios Geográficos, nº 170-171, págs. 171-186.

ROSSELLÓ I VERGER, V.M․ (1989): «Los llanos de inundación», en GIL OLCINA, A. y MORALES GIL, A. (Eds.), Avenidas fluviales e inundaciones en la Cuenca del Mediterráneo, Alicante, Instituto Universitario de Geografía, págs. 243-283.

RUIZ PÉREZ, J.M. (1996): «Hidrogeomorfología del abanico aluvial del río Magro», Cuaternario y Geomorfología, 10 (3-4), págs. 63-76.

RUIZ PÉREZ, J.M. (1998): «La avulsión del río Albaida en la llanura de inundación del Júcar (Valencia)», en GÓMEZ ORTIZ, A. y SALVADOR FRANCH, F. (Eds.): Investigaciones recientes de la geomorfología española, Barcelona, págs. 273-282.

RUIZ PÉREZ, J.M. (1998): «La desembocadura del Albaida (Siglos XVIII-XX): Una metamorfosis fluvial en la ribera del Xúquer», Cuadernos de Geografía, 63, págs. 39-65. 
RUIZ PÉREZ, J.M (En prensa): Dinámica fluvial y organización territorial: El Júcar desde Antella al río Albaida. Actas de la VII Assemblea d'historia de la Ribera, Sumacàrcer, Noviembre de 1998.

RUIZ, J.M y CARMONA, P. (1998): «Procesos hidrogeomorfológicos en el desbordamiento del río Júcar de otoño de 1997 (Litoral Mediterráneo, Valencia)», en GÓMEZ ORTIZ, A. y SALVADOR FRANCH, F. (Eds.): Investigaciones recientes de la geomorfología española, Barcelona, págs. 283-290.

SANCHIS IBOR, C. (1998): «Aiguamolls, marjals i sèquies: la transformació del paisatge medieval de Cullera», II Jornades d'Estudis de Cullera, Benicull, ed.7 i Mig, págs. 115-136.

SANCHIS IBOR, C. (2001): Regadiu i canvi ambiental a l'Albufera de València, València, Universitat de València.

SANCHO, A. y MONLEÓN, S. (1860): Dictamen facultativo sobre el proyecto formado por D.Juan Peyronet para alcanzar canalizar el río Júcar y poder fertilizar la provincia de Alicante, Valencia, Imprenta de J.M. Ayoldi.

TORRES FAUS, F. (2000): «La construcció de la séquia reial de Carcaixent en el segle XVIII», L'espai de l'aigua. Xarxes i sistemes d'irrigació a la Ribera del Xúquer en la perspectiva històrica, Ajuntament d'Alzira i Universitat de València, Valencia, págs. 189-204.

VERCHER LLETÍ, S. (2000): «Séquies i escorredors a la Ribera Baixa del Xúquer: la Vila i Honor de Corbera (segles XV-XVIII)», L'espai de l'aigua. Xarxes i sistemes d'irrigació a la Ribera del Xúquer en la perspectiva històrica, Ajuntament d'Alzira i Universitat de València, Valencia, págs. 141-162.

VIUDES HERNÁNDEZ, E. (1992): La Real Acequia de Carcagente...Historia y constitución de las Comunidades de Regantes de las Riberas del Júcar (Valencia), Valencia, Ministerio de Agricultura, Pesca y Alimentación, págs. 89-144. 